\title{
Never Let the Opportunity to Prepare for a Crisis Go to Waste: The Need for Proactive Measures in the Asia- Pacific Region to Mitigate the Impacts of Climate Change
}

\author{
A Monograph \\ by \\ MAJ Jeffrey P. Rhodes \\ United States Army

 \\ School of Advanced Military Studies \\ United States Army Command and General Staff College \\ Fort Leavenworth, Kansas \\ 2015-01
}

Approved for public release; distribution is unlimited 


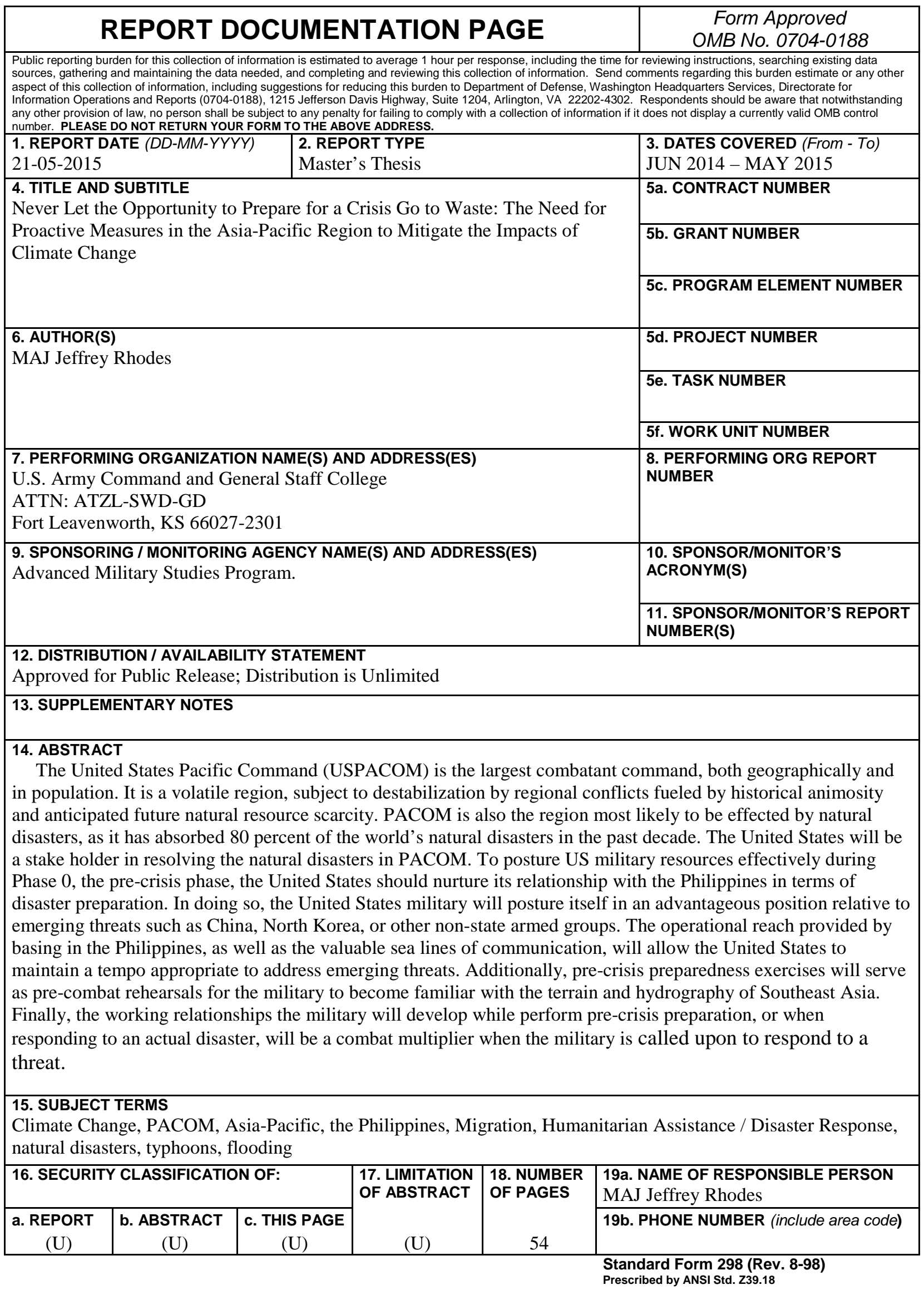




\section{Monograph Approval Page}

Name of Candidate: MAJ Jeffrey P. Rhodes

Monograph Title: Never Let the Opportunity to Prepare for a Crisis go to Waste: The Need for Proactive Measures in the Asia-Pacific Region to Mitigate the Impacts of Climate Change

Approved by:

, Monograph Director

Anthony E. Carlson, PhD

Seminar Leader

Yan Poirier, LCol, Canadian Army

, Director, School of Advanced Military Studies

Henry A. Arnold III, COL, IN

Accepted this 21st day of May 2015 by:

Robert F. Baumann, PhD

, Director, Graduate Degree Programs

The opinions and conclusions expressed herein are those of the student author and do not necessarily represent the views of the U.S. Army Command and General Staff College or any other governmental agency. (References to this study should include the foregoing statement.) 


\begin{abstract}
Never Let the Opportunity to Prepare for a Crisis Go to Waste: The Need for Proactive Measures in the Asia-Pacific Region to Mitigate the Impacts of Climate Change, by MAJ Jeffrey P. Rhodes, 54 pages.

The United States Pacific Command (USPACOM) is the largest combatant command, both geographically and in population. It is a volatile region, subject to destabilization by regional conflicts fueled by historical animosity and anticipated future natural resource scarcity.

USPACOM is also the region most likely to be effected by natural disasters, as it has absorbed 80 percent of the world's natural disasters in the past decade. The United States will be a stakeholder in resolving the natural disasters in USPACOM. To posture the US Military resources effectively during Phase 0, the pre-crisis phase, the United States should nurture its relationship with the Philippines in terms of disaster preparation. In doing so, the United States military will posture itself in an advantageous position relative to emerging threats in the USPACOM area of responsibility. The operational reach provided by basing in the Philippines, as well as the valuable sea lines of communication, will allow the United States to maintain a tempo appropriate to address emerging threats. Additionally, pre-crisis preparedness exercises will serve as precombat rehearsals for the military to become familiar with the terrain and hydrography of Southeast Asia. Finally, the working relationships the military will develop while perform precrisis preparation, or when responding to an actual disaster, will be a combat multiplier when the military is called upon to respond to a threat.
\end{abstract}




\section{Contents}

\section{Page}



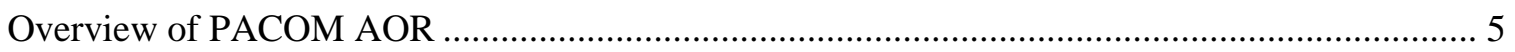

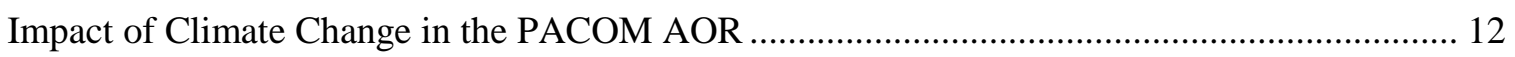

Precedent for Humanitarian Assistance and Disaster Response.................................................. 21

Case study in Doing HA/DR Wrong: Cyclone Nargis, Burma, 2008 ........................................ 23

Case study in Doing HA/DR Slightly Better: Typhoon Yolanda, the Philippines, 2013 .............. 25

Addressing These Challenges Efficiently: HA/DR Preparation in the Philippines....................... 29

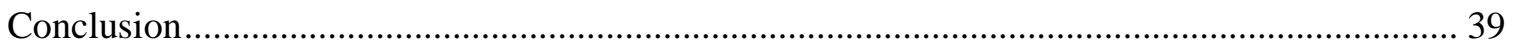






\section{Acronyms}

\begin{tabular}{|c|c|}
\hline ADP & Army Doctrine Publication \\
\hline AFP & Armed Forces of the Philippines \\
\hline AHA & ASEAN Co-ordinating Center for Humanitarian Assistance \\
\hline AKG & Al Khobar Group \\
\hline AOR & Area of Responsibility \\
\hline ASEAN & Association of South East Asian Nations \\
\hline ASG & Abu Sayyaf Group \\
\hline BIMF & Bangsamoro Islamic Freedom Movement \\
\hline CCAR & Climate Change Adaptation Roadmap \\
\hline CFE-DMHA & Center for Excellence in Disaster Management and Humanitarian Assistance \\
\hline CNA & Center for Naval Analyses \\
\hline CRED & Centre for Research on the Epidemiology of Disasters \\
\hline DART & Disaster Assistance Response Team \\
\hline DoD & Department of Defense \\
\hline DoS & Department of State \\
\hline EIA & Energy Information Administration \\
\hline GAO & Government Accountability Office \\
\hline GHG & Green House Gas \\
\hline GRP & Government of the Republic of the Philippines \\
\hline HA/DR & Humanitarian Assistance and Disaster Response \\
\hline IPCC & Intergovernmental Panel on Climate Change \\
\hline IS & Islamic State \\
\hline JTF & Joint Task Force \\
\hline NGO & Non-Governmental Organization \\
\hline NPA & New People’s Army \\
\hline NSAG & Non-State Armed Group \\
\hline
\end{tabular}




\begin{tabular}{ll} 
NSS & National Security Strategy \\
OCHA & Office for the Coordination of Humanitarian Affairs \\
PACOM & Pacific Command \\
PRC & People's Republic of China \\
QDR & Quadrennial Defense Review \\
SCS & South China Sea \\
SLOC & Sea Line of Communication \\
SRA & Southern Resource Area \\
UN & United Nations \\
UNICEF & United Nations International Children's Education Fund \\
US & United States \\
USAID & United States Agency for International Development \\
USG & United States Government \\
WFP & World Food Program \\
WMO & World Meteorological Organization \\
\hline
\end{tabular}


Introduction

On 5 February 2014, the United States Pacific Command (PACOM) Commander Admiral Samuel J. Locklear stated that the focus on Humanitarian Assistance and Disaster Relief (HA/DR) is critical to long-term regional stability. ${ }^{1}$ Over the past ten years, natural disasters have

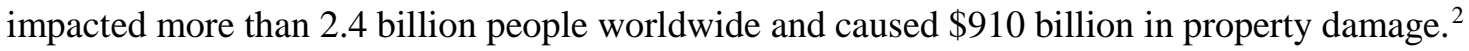
Remarkably, 80 percent of those natural disasters have occurred in the PACOM Area of Responsibility (AOR). According to the Center for Excellence in Disaster Management and Humanitarian Assistance (CFE-DMHA), a PACOM organization responsible for ensuring high quality disaster management and humanitarian assistance capabilities, this trend is a direct result of climate change and is projected to continue. ${ }^{3}$ The US Department of Defense (DoD) is well equipped to respond to natural disasters and has been assigned that mission by President Barack Obama as illustrated in the CFE-DMHA Strategy, FY 2014-2018. ${ }^{4}$ Along these same lines, countries suffering from natural disasters need specific support that only the DoD can provide. Beyond the immediately pressing need for military assistance following a natural disaster, it is prudent for the United States to leverage ancillary capabilities, such as the capacity building potential within the US Department of State (DoS) and the US Agency for International

${ }^{1}$ Samuel J. Locklear, “Press Conference, East Asia Pacific Media Hub,” PACOM, 5 February 2014, accessed 26 February 2015, http://www.pacom.mil/Media/SpeechesTestimony/ tabid/6706/Article/565152/adm-samuel-j-locklear-media-availability.aspx.

${ }^{2}$ Center for Excellence in Disaster Management and Humanitarian Assistance Strategy FY14-18 (Joint Base Pearl Harbor-Hickam, HI: Center for Excellence in Disaster Management and Humanitarian Assistance, 2014), 1, accessed 26 February 2015, https://www.cfedmha.org/LinkClick.aspx?fileticket=Y_TPmmK5_b8\%3d\&portalid=0.

${ }^{3}$ Ibid.

${ }^{4}$ Ibid., 3. 
Development (USAID), to prepare long term solutions for mitigating the deleterious impacts of future disasters in the PACOM AOR.

Senior military leaders have identified natural disasters in the PACOM AOR as a primary subject of concern. During a 6 December 2012 speech, PACOM Commander Admiral Locklear identified the future challenges of natural disasters when he listed climate change first among a list of regional challenges. ${ }^{5}$ Admiral Locklear's concern is reinforced by the 2007 Center for Naval Analyses (CNA) Corporation report National Security and the Threat of Climate Change. The report argued that climate change presents national security risks for the United States. It also recommends that "the US should commit to global partnerships that help less developed nations build the capacity and resiliency to better manage climate impacts.”6 The long-term regional stability of PACOM requires a proactive posture that identifies flashpoints and addresses antecedent conditions that could result in conflict. Global climate change likely exacerbates these conditions.

The urgency of a coordinated, multi-national response is not a belief held exclusively in the United States. The Association of Southeast Asian Nation States (ASEAN), an organization founded on 8 August 1967 has taken the initial steps to mitigate the impacts of natural disasters. Ten Southeast Asian nations, all residing within the PACOM AOR, compose ASEAN. The ASEAN charter identifies its second purpose as: "to enhance regional resilience by promoting

${ }^{5}$ Samuel J. Locklear, “News Briefing, Pentagon Briefing Room,” PACOM, 6 December 2012, accessed 2 August 2014, http://www.pacom.mil/Media/SpeechesTestimony/ tabid/6706/Article/565148/a-combatant-commanders-view-on-the-asia-pacific-rebalance-thepatch-work-quilt.aspx.

${ }^{6}$ CNA Corporation, National Security and the Threat of Climate Change (Alexandria, VA: CNA Corporation, 2008), 47. 
greater political, security, economic, and socio-cultural cooperation.”7 Pursuant to the charter's second purpose, the ASEAN Agreement on Disaster Management and Emergency Response in July of 2005 created the ASEAN Co-ordinating Centre for Humanitarian Assistance (AHA). The AHA exists "for the purpose of facilitating co-operation and coordination among the Parties, and with relevant United Nations and international organisations, in promoting regional collaboration." ${ }^{8}$ To that end, it collects information from member nations regarding their capabilities to provide disaster relief and facilitates cooperation. Nevertheless, the AHA does not own any material assets and relies upon voluntary assistance provided by member nations. The AHA constitutes an ideal opportunity for the DoS and USAID to initiate coordination with ASEAN to determine what each country identifies as its greatest natural disaster vulnerability. Armed with these data, the DoS could coordinate with both the ASEAN nations and with the DoD to facilitate more responsive reactions to future crises.

In the 2014 US fiscal environment, it is crucial that the DoD maintain strong partnerships with allied and partner nations in PACOM to deter aggression and to bolster regional influence. An excellent approach to forge goodwill among governments, militaries, and people is for the United States to leverage its military and civilian capabilities for HA/DR during future natural disasters in the PACOM AOR. Given the military and economic importance of the Asia-Pacific region and the sheer size of the Area of Operations (AO), both in terms of geography and population, it is critical that the United States leverage its limited resources wisely to strengthen

${ }^{7}$ Association of South East Asian Nations, The ASEAN Charter (Jakarta: ASEAN Secretariat, 2008), 3, accessed 18 January 2015, http://www.asean.org/archive/ publications/ASEAN-Charter.pdf.

${ }^{8}$ Association of South East Asian Nations, ASEAN Agreement on Disaster Management and Emergency Response (Vientiane 2005), article 20, accessed 3 December 2014, http://www.asean.org/communities/asean-socio-cultural-community/item/the-asean-agreementon-disaster-management-and-emergency-response. 
regional relationships and partnerships. This is an ideal opportunity to apply "smart power," defined by Joseph Nye as an intelligent mixture of hard power (coercive, often military options) and soft power (diplomatic solutions, economic incentives, or information management). ${ }^{9} \mathrm{~A}$ careful mixture of both hard and soft power, selectively applied during the pre-crisis period, can establish conditions favorable to the United States in the event of a regional conflict. Indeed, Nye defines a new political science theory, liberal realism, which addresses this phenomenon. ${ }^{10}$ Strategically, this will reinforce key international relationships in the AO during Phase 0, shaping the battlefield. Doctrinally, Phase 0 occurs prior to the initiation of hostilities and includes “joint and multinational operations inclusive of normal and routine military activities and various interagency activities are performed to dissuade or deter potential adversaries and to assure or solidify relationships with friends and allies.” ${ }^{11}$ To promote long-term regional stability in PACOM AOR, the United States Government (USG) should anticipate and prepare to respond to sudden onset disasters in the Philippines using the DoD. In addition, the USG must have the capability to react to humanitarian crises using the capabilities owned by the DoD, the DoS and USAID.

This monograph will evaluate what specific HA/DR contingencies in the Philippines, resulting from ongoing global climate change, the US DoD must prepare to address during Phase 0 operations to promote military cooperation with the Philippines and reinforce long-term

${ }^{9}$ Joseph S. Nye, The Future of Power (New York: Public Affairs. 2011). Joseph Nye identifies five steps to applying smart power. They are: first, setting clear and manageable objectives; second, determining what resources are available and how that availability will adapt to changing context; third, determining resources and preferences of the agent or actor that is the object of intended influence; fourth, deciding which type of power (command or co-optive) is most appropriate; and fifth, determining the likelihood of both tactical and strategic success.

${ }^{10}$ Ibid., 213.

${ }^{11}$ Joint Chiefs of Staff, Joint Publication (JP) 5-0, Joint Operational Planning (Washington, DC: Government Printing Office, 2011), xxiii. 
PACOM stability. These data will be particularly relevant to decision-makers as this monograph’s conclusions validates the President’s Pacific Rebalancing strategy and postures the United States to respond to PACOM AOR environmental contingencies.

Overview of PACOM AOR

Currently, the US military has a presence in the Pacific and, pursuant to the "Pacific Rebalance,” the DoD will allocate more combat power to the region. ${ }^{12}$ Though the Pacific Rebalance policy will rotate additional service members through PACOM on either a permanent or temporary basis, the United States' military budget is shrinking due to sequestration. As a result of fiscal reductions, the United States will not be able to commit the total number of naval vessels to the PACOM as planned for during the Pacific Rebalance. ${ }^{13}$ For this specific reason, the most appropriate location for the DoD to conduct joint exercises and planning to respond to natural disasters is the PACOM AOR. The PACOM AOR is significant because of geographic size, dense population, and vulnerability to climate change. PACOM shares borders with all of the other five geographic combatant commands and it includes 36 nations (five of which are allied with the United States via defense treaties). The AOR includes the world's most populous country, the largest democracy, and the most populous nations where a majority of the population are Muslim. PACOM covers 50 percent of the world's population, 3,000 different languages, two of the three largest economies, and ten of the fourteen smallest economies. Commercially, the PACOM AOR has the world's busiest sea lane, which affords access to nine of the world's ten largest ports and the Strait of Malacca. This is critical because the US Energy Information

\footnotetext{
${ }^{12}$ Hearing before the Senate Armed Services Committee, Defense Authorization Request and Future Years Defense Program, 113th Cong., 1st sess., 25 March 2014.

${ }^{13}$ Ibid.
} 
Administration (EIA) considers the Strait of Malacca one of the world's two most strategic choke points from the perspective of oil transit. ${ }^{14}$ From a military perspective, the PACOM AOR includes seven of the world's ten largest militaries and five of the world's declared nuclear nations. Small wonder it is difficult to overstate PACOM's strategic significance. ${ }^{15}$

There are many potential military threats in PACOM as well, including adversaries ranging from near-peer competitor China to armed non-state groups seeking to overthrow local governments. The People’s Republic of China (PRC) is increasing military expenditures and modernizing, and it holds enough US debt to impact the United States economically if it were to sell some of the debt or undervalue its own currency. The Democratic People’s Republic of Korea (DPRK) can destabilize the region militarily and has demonstrated a proclivity towards antagonizing its neighbors by sinking a South Korean submarine, killing two South Korean civilians during an artillery attack, and testing missile ranges to provoke Japan. Though not a direct threat to the United States, regional instability resulting from North Korean aggression against either South Korea or Japan would be detrimental to US interests. Several other factors could potentially provoke a regional conflict. For instance, China, the Philippines, Brunei, Malaysia, Taiwan, and Vietnam have overlapping claims to portions of the South China Sea. These islands, and the food, energy, and mineral resources they include will likely increase in value as the impacts of climate change take hold. In addition, the notoriously unpredictable nature

${ }^{14}$ US Energy Information Administration, World Oil Transit Chokepoints, November 2014, 1, accessed 25 February 2015, http://www.eia.gov/countries/analysisbriefs/ World_Oil_Transit_Chokepoints/wotc.pdf.

${ }^{15}$ US Pacific Command, “USPACOM Area of Responsibility,” accessed 26 February 2015, http://www.pacom.mil/AboutUSPACOM/USPACOMAreaofResponsibility.aspx. 
of the DPRK and the recent Pacific Rebalance of the United States perhaps allow a greater window for potential armed conflict. ${ }^{16}$

Ever since the 1990s, China's military budget has been expanding with an emphasis towards maritime capabilities. China began flexing its maritime muscle during the 1995-1996 Taiwan Strait crisis. During the period between 21 July 1995 and 25 March 1996, China conducted a series of military exercises designed to intimidate Taiwan from seeking full independence and send a message to the United States that it maintains an ability to project power. These shows of force ranged from a three-day exercise involving the firing of two missiles per day from 21-23 July 1995, less than 50 miles from Taiwan’s ports, to a full-scale amphibious exercise from 12-25 March 1996 involving 40 naval vessels, 260 aircraft, and an estimated 150,000 soldiers. ${ }^{17}$ Since that time, China has increased its military budget and consistently improved its land-based and maritime capabilities. As recently as March 2014, Chinese leaders announced they were increasing their military budget by 12 percent. China is now second only to the United States in military spending. ${ }^{18}$ Although, the PRC reported a 12.2 percent increase to \$132 billion in its budget from 2013 to 2014, the Defense Intelligence Agency (DIA) believes that much of China underreported its spending and that the real total is closer to $\$ 240$ billion. ${ }^{19}$

${ }^{16}$ West Philippine Sea Informal Expert Group, “Towards a Strategic Framework for Management of the West Philippine Sea” (White Paper, 2012), 2, 3, 5, accessed 26 November 2014, http://www.imoa.ph/towards-strategic-framework-management-west-philippine-seal-whitepaper-wps-informal-expert-group/.

${ }^{17}$ Andrew Scobell, "Show of Force: The PLA and the 1995-1996 Taiwan Strait Crisis” (Asia/Pacific Research Center, January 1999), 5, accessed 10 February 2015, http://iisdb.stanford.edu/pubs/10091/Scobell.pdf.

${ }^{18}$ Hearing before the Senate Armed Services Committee, Defense Authorization Request and Future Years Defense Program, 113th Cong., 1st sess., 25 March 2014.

${ }^{19}$ William Wan. “As Budgets Soar, China Still Fears Its Military Isn’t Growing Fast Enough,” The Washington Post, 7 March 2014, accessed 26 November 2014, 
Despite this increase in spending, the actual Soldier end-strength of the People's Liberation Army (PLA), People’s Liberation Army Navy (PLAN), and People’s Liberation Army Air Force (PLAAF) has decreased from roughly 3.1 million Soldiers total 1990 to 2.3 million in $2014 .{ }^{20}$ Given the approximate increase in military spending, the reduction in end strength can be explained by the modernization of the remaining forces, in particular the PLAN and PLAAF. ${ }^{21}$ The resulting force, both more modernized and more technical, is the realistic result of a China that will seek to secure greater global interests in the coming decade in response to a broader group of stakeholders for both its foreign and security policy. ${ }^{22}$

On 23 November, 2013 China announced an ADIZ (Air Defense Identification Zone) over the Senkaku islands. ${ }^{23}$ The ADIZ expands beyond China's territorial sovereignty, and serves as a requirement that China has placed on foreign aircraft to identify themselves upon entering the specified area. ${ }^{24}$ Additionally, China is developing more mature anti-access / area denial (A2/AD) technology to target what they view as a critical strength and vulnerability of the United States: aircraft carriers. The PLAN has a modernized submarine force, and its current surface ship capability includes frigates with guided missiles as well as guided missile destroyers. ${ }^{25}$ This

http://www.washingtonpost.com/world/asia_pacific/as-budgets-soar-china-still-fears-its-militaryisnt-growing-fast-enough/2014/03/06/e90c448a-a52e-11e3-84d4-e59b1709222c_story.html.

${ }^{20}$ Michael S. Chase et al., China's Incomplete Military Transformation: Assessing the Weaknesses of the People's Liberation Army (Santa Monica, CA: RAND Corporation, February 2015), 54.

${ }^{21}$ Chase et. al., 15.

${ }^{22}$ Ibid., 62.

${ }^{23}$ Zachary Keck, “China Imposes Restrictions on Airspace Over Senkaku Islands,” The Diplomat, 23 November 2013, accessed 19 February 2015, http://thediplomat.com/2013/11/ china-imposes-restrictions-on-air-space-over-senkaku-islands/.

${ }^{24} \mathrm{An}$ ADIZ is an informal control measure, neither explicitly allowed nor prohibited under international law.

${ }^{25}$ Chase et. al., 15. 
increase in spending, coupled with the ending of China's "charm offensive," suggests that the country is prepared to use more coercive measures to project strategic power or adjudicate international disputes.

China's economy continues to grow at a rate of roughly nine percent annually. Much of this growth is contingent upon commerce along the SLOCs in the South China Sea and the South East Asian Straits. Indeed, 75 percent of China’s GDP is dependent upon trade, much of which passes through these sea lanes. China is also negotiating strategic partnerships with many of its neighbors, including Vietnam. Though not powerful enough to challenge the United States in a traditional sea conflict, the PLAN has developed strategies of asymmetric warfare to make the opportunity cost of US involvement in any regional conflict prohibitively expensive, thus expanding its own regional influence.

The PLAN also continues to modernize ships, weapons, and systems. Specifically, the PLAN seeks to improve its ability to engage other ships at sea and at greater ranges from the Chinese mainland. As early as 2020, China could potentially field up to 60 submarines capable of delivering either intercontinental ballistic missiles (ICBMs) or anti-ship cruise missiles. The PLAN's expanded capabilities could potentially be used to engage US assets that were previously out of its reach (such as Guam). Finally, the increased sea presence of the PLAN allows it to field test equipment and improve its best practices. ${ }^{26}$

Though coercive power is an option, the Chinese may influence US actions in the Pacific using other tools. The 2010 US Quadrennial Defense Review Report (QDRR) recognizes the significance of China’s economic ascendency and economic strength: “China’s growing presence and influence in regional and global economic and security affairs is one of the most

${ }^{26}$ US-China Economic and Security Review Commission: 2013 Report to Congress (Washington, DC: Government Printing Office, 2013), 233, accessed 6 December 2014, http://www.uscc.gov/Annual_Reports/2013-annual-report-congress. 
consequential aspects of the evolving strategic landscape in the Asia-Pacific region and globally.”27 This is crucial because of China's suspected strategy of making US involvement in the South China Sea cost prohibitive. ${ }^{28}$ China can also apply economic pressure, as the Chinese currently own approximately of $\$ 1$ trillion in US debt. ${ }^{29}$ They could punish undesirable US action in the South China Sea by either selling debt, and thus devaluing the US dollar, or by deliberately undervaluing their own currency, the renminbi, to place themselves in a more advantageous trade or investment position. In 2010, retired Major General Luo Yuan addressed this possibility to China’s Outlook Weekly magazine, stating: "We could sanction them using economic means, such as dumping some US Government bonds," ${ }^{30}$ This would depreciate the value of the US dollar as the purchaser would require a higher interest rate to buy them. ${ }^{31}$ Given these coercive tools, the United States would need to conduct analysis and planning far in excess of comparative force ratios to gauge the threat that the PRC poses, to include economic coercion.

A more violent threat to the United States in PACOM AOR is the DPRK. The Military and Security Developments of the Democratic People’s Republic of Korea 2013 identifies the DPRK's strategic goals as international recognition as a nuclear-armed state, maintenance of a

${ }^{27}$ Ryan Clark, “Chinese Energy Security: The Myth of the PLAN's Frontline Status” (Letort Papers, U.S. Army War College, Strategic Studies Institute, Carlisle, PA, 2010), 28-32.

${ }^{28}$ Ibid., 32.

29“"China Holds More US Debt than Indicated,” Washington Times, 2 March 2010, accessed 26 February 2015, http://www.washingtontimes.com/news/2010/mar/2/chinas-debt-tous-treasury-more-than-indicated/.

30 "China Holds More US Debt than Indicated,” Washington Times, 2 March 2010, accessed 26 February 2015, http://www.washingtontimes.com/news/2010/mar/2/chinas-debt-tous-treasury-more-than-indicated/.

${ }^{31}$ Wayne M. Morrison and Marc Labonte, China's Holdings of U.S. Securities: Implications for the U.S. Economy (Washington, DC: Congressional Research Service, 2008), 8, accessed 23 November 2014, http://fpc.state.gov/documents/organization/99496.pdf. 
viable deterrent capability, and reunification of the Korean peninsula under its control. ${ }^{32}$ While not at the same competitive level as the PLA, the North Korean Navy (NKN) demonstrated its willingness to use violence on the peninsula in 2010 by sinking the South Korean naval vessel Cheonan. The NKN has seventy submarines currently in use, distributed between the east and west coasts of the peninsula. ${ }^{33}$ While not capable of projecting power far beyond its territorial waters, the NKN remains a potent regional threat.

In addition to the threats posed by the China and the DPRK, the United States may be drawn into an armed conflict caused by a territorial dispute among regional powers. Most notably, six nations dispute territorial ownership in the South China Sea, valuing the area for its natural resources, fisheries, and sea lanes. The value of the sea lanes at stake in the South China Sea would involve the United States in any regional dispute. China, the Philippines, Taiwan, Vietnam, Brunei, and Malaysia all wage competing claims across overlapping portions of the South China Sea. The three disputed territorial boundaries include the Panatag Island shoal, the Paracel Islands, and the Spratly Islands in the South China Sea. Though the islands are uninhabitable, the land itself and the surrounding waters include economic resources. Under the water itself, an estimated two hundred billion barrel oil reserve rests in the sea bed. From a food security standpoint, there is a fishing potential of \$97 billion annually to be harvested from the fisheries located around the island chains. The territory also holds large reserves of manganese, nickel, copper, and cobalt ready for extraction. Finally, the sea lanes themselves reach from the

${ }^{32}$ Department of Defense, Military and Security Developments Involving the Democratic People's Republic of Korea 2013 A Report to Congress Pursuant to the National Defense Authorization Act for Fiscal Year 2012 (Washington, DC, 2013), 6, accessed 1 December 2014, http://www.defense.gov/pubs/North_Korea_Military_Power_Report_2013-2014.pdf.

${ }^{33}$ Ibid. 
Persian Gulf to both the South China Sea and the Pacific Ocean. ${ }^{34}$ With such enormous economic value, it should come as no surprise that nations compete for ownership of the area. Since 1978, the Philippine government has asserted ownership of the islands and their resources. ${ }^{35}$ Three other countries; China, Taiwan and Vietnam argue that historical maps and records demonstrate their rightful ownership of portions of the area. Finally, Brunei and Malaysia hold the position that the geography of the continental shelf establishes their right to those lands. With so many competing claims, and each nation using a different justification for claiming the islands, the sea lanes, and the valuable resources they contain, it should be clear that these overlapping claims could invite violence in establishing territorial sovereignty.

Impact of Climate Change in the PACOM AOR

Over the past 250 years (prior to the Industrial Revolution), the amount of carbon dioxide in the atmosphere has increased by forty percent to 391 parts per million (ppm). ${ }^{36}$ This is a greater concentration than the planet has experienced for at last the previous 8000,000 years. ${ }^{37}$ The scientific community agrees overwhelmingly that the climactic changes measured since 1950 are unprecedented. ${ }^{38}$ Another layer of complexity of the overall environmental impact of the

${ }^{34}$ Sherman O. Cruz, "Possible Scenarios on the Future of the Panatag Shoal (Huangyan Island/ Scarborough Shoal): Controversy using Jim Dator's Four Archetypes of Alternative Futures,” Journal of Future Studies 18, no. 2 (December 2013): 35-36.

${ }^{35}$ Ibid, 36.

${ }^{36}$ Intergovernmental Panel on Climate Change, 2014: Summary for Policy Makers. In: Climate Change 2014: Impacts, Adaptation, and Vulnerability. Contribution of Working Group II to the Fifth Assessment Report of the Intergovernmental Panel on Climate Change, (Cambridge, United Kingdom and New York, USA: Cambridge University Press, 2014), accessed May 01, 2015, http://www.ipcc.ch/pdf/assessment-report/ar5/wg1/WG1AR5_SPM_FINAL.pdf., 11.

${ }^{37}$ Ibid.

${ }^{38}$ Ibid., 4. 
release of carbon dioxide into the atmosphere is the carbon fertilization effect. Abundant carbon dioxide, the primary ingredient of photosynthesis, can allow plants to thrive while using less water if the temperature remains relatively cool. As a result, increased levels of carbon dioxide can increase crop yields for certain staple foods such as rice, wheat, and soybeans from eight percent to 50 percent depending on conditions. The carbon fertilization effect may seem at first to be an opportunity for people to have more productive agricultural yields; however, temperature is another variable. Areas where the temperature is already approaching the higher threshold at which crops can thrive, such as West Asia and Africa, will face a reduction in the crop yields as a result of higher temperatures. ${ }^{39}$

As global temperatures rise, the temperature of the oceans increases as well, and water expands as it warms. This, in conjunction with melting polar ice, contributes to rising sea levels. Rising sea levels will contribute to more significant flood and wind damage along the coastal regions; even absent an increase in the tropical storms' intensity. ${ }^{40}$ Accordingly, it is challenging to predict how soon the frequency and intensity of severe weather events will increase, underscoring the urgency for the United States to plan adaptation efforts. ${ }^{41}$ Planners must guard against taking a reductionist view of “if condition X exists, result $\mathrm{Y}$ will logically follow” to safeguard against suggesting either inappropriate or incomplete solutions. ${ }^{42}$

${ }^{39}$ Nicholas Stern, The Economics of Climate Change: The Stern Review (Cambridge: Cambridge University Press, 2007), 82-83.

${ }^{40}$ David G. Victor, Climate Change: Debating America's Policy Options (New York: Brookings Institute Press, 2004), 147.

${ }^{41}$ CNA Corporation, 1.

${ }^{42}$ In "The Logic of Failure: Recognizing and Avoiding Error in Complex Situations," Dietrich Dorner gives several examples of intelligent, well-intentioned managers attempting to reduce complex, systemic problems to cause and effect dynamics with quick, obvious solutions. While universally effective in the short term, the examples invariably lead to long term systemic instability, attributed to managers failing to properly appreciate the complexity of the 
The US DoD recognizes and is working to mitigate the impacts of climate change. In the 2014 Climate Change Adaptation Roadmap (CCAR), then US Secretary of Defense Chuck Hagel explained the widening challenges of the US DoD in confronting the global impacts of climate change. ${ }^{43}$ Hagel stated: “Climate change does not directly cause conflict, but it can significantly add to the challenges of global instability, hunger, poverty and conflict. Food and water shortages, pandemic disease, disputes over refugees and resources, more severe natural disasters all place additional burdens on economies, societies, institutions, and the world." ${ }^{44}$ The CCAR further explains how these conditions can challenge stable governments by increasing competition over resources, and directly threaten fragile governments by highlighting their inability to respond effectively to crises. ${ }^{45}$ Both the 2010 and 2014 QDRs also identified climate change as a national security threat. The 2014 QDR states "climate change poses another significant challenge for the United States and the world at large," and continues that "climate change may exacerbate water scarcity and lead to sharp increases in food costs. The pressures caused by climate change will influence resource competition while placing additional burdens on economies, societies, and governance institutions around the world.” ${ }^{46}$ As recently as 20 January 2015, during his annual State of the Union address to the US Congress, President Obama echoed these sentiments: “The Pentagon says that climate change poses immediate risks to our national

relationships within the system. Dietrich Dörner. The Logic of Failure: Recognizing and Avoiding Error in Complex Situations (New York: Basic Books, 1996), Chapter 1.

${ }^{43}$ Department of Defense, FY 2014 Climate Change Adaptation Roadmap, June 2014, accessed 18 February 2015, http://www.acq.osd.mil/ie/download/CCARprint.pdf.

${ }^{44}$ Ibid., 1.

${ }^{45}$ Ibid., 4.

${ }^{46}$ Department of Defense. 2014 Quadrennial Defense Review (Washington, DC: Government Printing Office, 2014), 8. 
security. We should act like it." ${ }^{47}$ The US Senate, the senior deliberative body of the legislative branch of the USG, concurred with the analysis of the President, the DoD, the PACOM commander, the Intergovernmental Panel on Climate Change (IPCC), the Centre for Research on the Epidemiology of Disasters, and ASEAN. In a rare demonstration of bipartisanship, the Senate on 21 January 2015 passed a resolution stating that "climate change is real and not a hoax." ${ }^{48}$ The vote tally was $98-1 .{ }^{49}$ During the last 30 years, hydro-meteorological disasters accounted for roughly three-fourths of all disasters in the Pacific. ${ }^{50}$ Hydro-meteorological disasters include floods, cyclones, desertification, and drought. Significantly, tropical cyclones accounted for half of those hydro-meteorological events. ${ }^{51}$ The CRED, a non-profit World Health Organizationaffiliated center that promotes research and training for humanitarian emergencies and natural disasters, notes the frequency of hydro-meteorological disasters, specifically tropical cyclones and the resultant flooding, has increased over the past few decades.

There are three significant commonalities among climate-change related disasters. First, greenhouse gas (GHG) concentration impact the climate variables of temperature and precipitation by changing GHG density. Second, temperature and precipitation alterations influence the pattern of climate hazards. Finally, natural disasters increase in direct proportion to

${ }^{47}$ Barack Obama, “Address Before a Joint Session of Congress on the State of the Union,” Code of Federal Regulations, title 3 (20 January 2015).

${ }^{48}$ To Express the Sense of the Senate that Climate Change is not a Hoax, 114th Cong, 1st sess., Congressional Record, vol. 161, daily ed. (21 January 2015), S. Amdt. 29 to S. Amdt. 2 to S1.

${ }^{49}$ Ibid.

${ }^{50}$ Paula Holland, "Statistical Summary: Hydrometeorological Disasters in the Pacific” (SPC SOPAC Published Report (PR187), 2014), 2, accessed 25 February 2015, http://www.wmo.int/sids/sites/default/files/Statistical\%20Summary\%20\%20Hydrometeorological\%20Disasters\%20in\%20the\%20Pacific.pdf.

${ }^{51}$ Holland, 2. 
climate-related hazards. The deleterious impacts of those natural disasters grow with even a modest increase in population density. Specific to the Asia-Pacific region, a population increase of one percent per square kilometer correlates with an addition 1.2 percent annual frequency of hydro-meteorological disasters in a given country. ${ }^{52}$

The 2007 report by the Center for Naval Analysis referenced at the beginning of this monograph, National Security and the Threat of Climate Change, is corroborated by a scientific consensus, articulated in the published findings of the IPCC. Established in 1988, the IPCC constitutes a body of scientists from 195 countries. ${ }^{53}$ Empowered by the United Nations Environmental Program (UNEP) and the World Meteorological Organization (WMO), the IPCC exists to provide a "clear scientific view on the current state of knowledge on climate change and its potential environmental and socio-economic impacts.”54 The IPCC predicts that by 2099, temperatures globally will rise by 3 degrees Celsius. ${ }^{55}$ Pollutant gasses currently in the atmosphere will not naturally dissipate from the environment for 10 to 100 years. As a result, even an immediate moratorium on the release of greenhouse gasses will not immediately reduce the current level of atmospheric pollution. ${ }^{56}$ David G. Victor synthesizes these data to predict that ongoing global climate change will trigger more frequent droughts, floods, and other extreme

${ }^{52}$ Vinod Thomas, Jose Ramon G. Albert, and Cameron Hepburn, "Contributors to the frequency of intense climate disasters in Asia-Pacific countries,” Springerlink.com, 2014, 2, 8, accessed 1 December 2014, http://reliefweb.int/sites/reliefweb.int/files/resources/Contributors\%20to\%20the\%20frequency\%2 0of\%20intense\%20climate\%20disasters\%20in\%20Asia\%20Pacific\%20countries.pdf.

${ }^{53}$ Intergovernmental Panel on Climate Change, “Organization,” accessed 3 October 2014, http://www.ipcc.ch/organization/organization.shtml.

${ }^{54}$ Intergovernmental Panel on Climate Change, “Organization,” accessed 3 October 2014, http://www.ipcc.ch/organization/organization.shtml.

${ }^{55}$ Victor, 139.

${ }^{56}$ Ibid., 143. 
weather events. ${ }^{57}$ Human responses, though often well intentioned, can intensify the challenges that natural disasters present and overburden the response system. To exemplify this, rising sea levels, increased flooding, and unpredictable weather patterns resulting from climate change will contribute to unplanned human migration. ${ }^{58}$ Extreme weather events can damage infrastructure, leaving large groups of people homeless in the short term. For example, when Typhoon Washi made landfall on the island of Mindanao in the Philippines in December 2011, it displaced more than 300,000 Filipinos from the cities of Cagayan de Oro and Iligan. Absent proper relocation facilities, a host of public health issues emerged. ${ }^{59}$ Science is not specific enough to predict with accuracy when or to what degree climate change-induced migration will occur within the PACOM AOR. To study the migration issue, the Asia Development Bank recommends collecting more migration data in their document Addressing Climate Change and Migration in Asia and the Pacific. ${ }^{60}$

In addition to unanticipated migration, global climate change drives natural resource scarcity. In the PACOM AOR, this may occur through water scarcity, ocean acidification, soil erosion, or depletion of fisheries. Inhabitants of a region subject to growing resource scarcity must determine how to best to adapt to their less plentiful environment. Unanticipated migration

${ }^{57}$ Intergovernmental Panel on Climate Change, Climate Change 2007: Impacts, Adaptation and Vulnerability (New York: Cambridge University Press, 2007), 11, accessed 25 February 2015, http://www.ipcc.ch/publications_and_data/publications_ipcc_fourth_assessment_report_wg2_rep ort_impacts_adaptation_and_vulnerability.htm.

${ }^{58}$ Koko Warner, "Environmental Change and Migration: Methodological Considerations from Ground-Breaking Global Survey, " Population and Environment 33, no. 1 (2011): 3-27, accessed 2 August 2014, http://search.proquest.com/docview/895310004?accountid=28992.

${ }^{59}$ Asia Development Bank, Addressing Climate Change and Migration in Asia and the Pacific (Mandaluyong City, Philippines: Asian Development Bank, 2012), 5.

${ }^{60}$ Ibid., 53. 
can exacerbate patterns of scarcity as demand for food, potable water, and suitable living spaces increases. Furthermore migrants tend to be low skilled workers who move from rural to urban areas. ${ }^{61}$ Calamitous weather events resulting in secondary humanitarian emergencies (such as unplanned migration) can establish conditions for true crises: violent competition or coercive measures employed by armed groups to maintain control over scarce resources.

Human responses to climate change induced crises are sometimes criminal in nature. ${ }^{62}$ In 2008, the Chairman of the National Intelligence Council, Thomas Finger, identified the potential for a threat to a nation's stability if diminished fresh water supplies resulted in armed conflict between factions in a state. ${ }^{63}$ Chad Briggs, head of the Energy and Environmental Security department at the US Air Force’s Air University, echoed these concerns in $2010 .{ }^{64}$ Briggs argued that the notion of resource scarcity is a potent catalyst for violence during insurgencies in developing countries. He notes that the most recent data troublingly suggests that environmental systems are much more sensitive to climate change than previous data suggested. Briggs introduces several planning considerations that provide a broader understanding of the operational environment produced from resource scarcity. These planning factors include: the impact on agriculture and the area's agricultural output; population migrations due to the absence of potable water; the inability to produce drinking water or food will delegitimize the

${ }^{61}$ Ibid., 17.

${ }^{62}$ Christian Webersik, Climate Change and Security: A Gathering Storm of Global Challenges (Denver: Praeger, 2010), xviii.

63 Thomas Fingar, Global Trends 2025: A Transformed World (Washington, DC: National Intelligence Council, 2008), 66.

${ }^{64}$ Chad M. Briggs, “Environmental Change, Strategic Foresight, and Impacts on Military Power,” Parameters 40, no. 3 (Autumn 2010): 76-90. 
government; and how these factors will converge to fuel the insurgency. ${ }^{65}$ He provides historical examples of insurgent groups targeting natural resources such as fresh water and food sources to exacerbate shortages, delegitimizing occupation governments in both Iraq and Afghanistan. ${ }^{66}$

Recently, the Islamic State (IS) leveraged its control over water resources to exert control over portions of Iraq. IS, the transnational Sunni-Islamist extremist network, also known the Islamic State of Iraq and the Levant (ISIL), has asserted control over parts of Northern Iraq and Northern Syria since 2013. ${ }^{67}$ Identified as a terrorist organization by the DoS, ${ }^{68}$ the group recently confiscated fresh water sources as a vehicle to increase its coercive influence. IS seized the Mosul dam, Iraq's largest dam, for almost two weeks in August 2014. ${ }^{69}$ Though the seizure of the Mosul dam was significant, it was not as damaging as the IS control of the Fallujah dam. Earlier in the year, IS manipulated the Fallujah dam to intimidate people of the Anbar province. Though the Fallujah dam is back under Iraqi control, the Deputy Head of the Anbar Provincial Council told Iraqi News that "water had destroyed the agricultural areas when the elements of the Islamic State of Iraq and Levant closed the dam gates." ${ }^{\prime 70}$ As IS has demonstrated in the previous examples, control and malicious manipulation of fresh water resources by terrorist organizations can result

${ }^{65}$ Ibid., 86.

${ }^{66}$ Ibid., 82.

${ }^{67}$ Kenneth Katzman et al., The "Islamic State” Crisis and U.S. Policy (Washington, DC: Congressional Research Service, February 2015), 1.

${ }^{68}$ US Department of State, “Foreign Terrorist Organizations,” accessed 29 January 2015, http://www.state.gov/j/ct/rls/other/des/123085.htm.; Coral Davenport, "Pentagon Signals Security Risks of Climate Change,” The New York Times, 13 October 2014.

${ }^{69}$ Ahmad Al- Rubaye, “Islamic State Seizes Iraq’s Largest Dam,” Aljazeera America, 7 August 2014, accessed 25 February 2015, http://america.aljazeera.com/articles/2014/8/7/iraqimilitants-seizecountryslargestdam.html.

${ }^{70}$ Layla Mohammad, “All Gates of Fallujah Dam Open, Says Esawi,” Iraqi News, 13 April 2014, accessed 25 February 2015, http://www.iraqinews.com/features/all-gates-offallujah-dam-open-says-esawi/. 
not only in potable water shortages, but also significant property damage and reduced agricultural output. Had IS or another terrorist organization seized the dams during a time of drought, one can imagine the ecological impact would have been greater still.

In 1995, Professor Thomas Homer-Dixon predicted that global climate change, and the resulting natural resource scarcity, might lead to crimes just as IS committed in the above Iraqi dam examples. ${ }^{71}$ Homer-Dixon, a professor of political science at the University of Waterloo, evaluated threats to security in the twenty-first century with emphases on climate change, resource scarcity, and economic instability. ${ }^{72}$ He concludes that the key to preventing societal friction resulting from resource scarcity in the present is ingenuity, with particular emphasis on efficiency in marketplaces and resource distribution. ${ }^{73}$ The damage IS caused to agriculture and the local Iraqi people in Fallujah in 2014 validates his prediction that malevolent actors will use resource scarcity as a point of leverage. The Fallujah and Mosul examples also serve as a model for what happens when marketplaces and resource distribution are deliberately inefficient: the populace suffers greatly.

In the PACOM AOR, the governments of Oceania are already debating how to face this daunting challenge. ${ }^{74}$ They are determining where they will displace their populations once their islands are no longer inhabitable because of submersion due to rising sea levels or subject to violent weather patterns that make continued habitation untenable. PACOM commander Admiral

${ }^{71}$ Thomas Homer-Dixon, “The Ingenuity gap: Can Poor Countries Adapt to Resource Scarcity?” Population and Development Review 21, no. 3 (September 1995): 587-612.

72 Thomas Homer-Dixon, “Biography,” Thomas Homer-Dixon professional website, accessed 18 January 2015, http://www.homerdixon.com/biography/.

${ }^{73}$ Homer-Dixon, “The Ingenuity gap,” 605.

${ }^{74}$ Oceania is the area in the Pacific Ocean consisting of Micronesia, Melanesia, Polynesia, Australia, and the Malay Archipelago. 
Locklear stated that the second order effect of this migration will be greater demand for limited resources, including fresh water and food. Multiplying this challenge, large cities in the Pacific region generally maintain between 48 to 72 hours-worth of food on hand. ${ }^{75}$ A large-scale migration, planned or unplanned, would stress this system. And as the IS example demonstrated, non-state armed groups do in fact use food and water scarcity as a coercive tool. In the PACOM AOR, The Philippines is among the three Pacific countries most likely to produce environmental refugees (the other two being Indonesia and Sri Lanka). Conversely, the most likely destinations for environmentally displaced people are Brunei, Japan, the Republic of Korea, Singapore, and China. $^{76}$

Precedent for Humanitarian Assistance and Disaster Response

Legal, doctrinal, and historical precedents exist for the United States to perform HA/DR missions in PACOM. US JP 3-16, Multi-National Operations supports HA/DR missions in the context of security cooperation. It states that these missions can "build defense relationships that promote specific US security interests, develop allied and friendly military capabilities for selfdefense and multi-national operations, and provide US forces with peacetime contingency access to a host nation." 77

${ }^{75}$ Samuel J. Locklear, “Asia-Pacific rebalance: Defending Shared Domains,” (Conference of Defence Associations, Ottawa, Ontario, Canada, 21 February 2013), accessed 2 August 2014, http://www.pacom.mil/Media/SpeechesTestimony/tabid/6706/Article/5275/asiapacific-rebalance-defending-the-shared-domains.aspx.

${ }^{76}$ Asia Development Bank, 2.

77 Joint Chiefs of Staff, Joint Publication (JP) 3-16, Multi-National Operations (Washington, DC: Government Printing Office, 2013), ix. 
Furthermore, the 2014 CCAR set conditions for HA/DR in goal three and in two of the four lines of effort (LOEs). ${ }^{78}$ Goal 3 states: "Collaborate with internal and external stakeholders on climate change challenges." ${ }^{79}$ In addition LOE 2 maintained that: "Training and Testing” emphasizes the importance of access to a training environment that approximates the environment in which the military will operate. ${ }^{80}$ The CCAR directs a review of deliberate planning to include theater operations as well as country-specific cooperation and engagement. ${ }^{81}$ It also clarifies that statement by directing collaboration between the DoS and foreign militaries and partner nations to maximize efficiencies in planning, improve vulnerability assessments, and enhance resistance to the impacts of climate change.

The DoS has issued complementary guidance in its Joint Strategic Plan (JSP) for the DoS and the USAID for fiscal years 2014-2017. ${ }^{82}$ This JSP is the DoS's answer to President Obama's National Security Strategy and compliments the National Defense Strategy and National Military Strategy, emphasizing DoS and USAID capabilities. Specifically, Strategic Goal 2 is to "strengthen America’s foreign policy impact on our strategic challenges." ${ }^{83}$ Strategic Goal 3 is to "promote the transition to a low emission, climate-resilient world while expanding global access to sustainable energy." ${ }^{84}$ Strategic Goal 4 is to "protect core US interests by advancing

\footnotetext{
${ }^{78}$ Department of Defense, FY 2014 Climate Change Adaptation Roadmap, 1, 9, 13.

${ }^{79}$ Ibid., 12.

${ }^{80}$ Ibid., 5.

${ }^{81}$ Ibid., 10.

${ }^{82}$ US Department of State, U.S. Department of State-USAID FY 2014-2017 Joint Strategic Plan (Washington, DC: Department of State, 2014).

${ }^{83}$ Ibid., 15.

${ }^{84}$ Ibid., 25.
} 
democracy and human rights and strengthening civil society." 85 The DoS further clarified objectives within those strategic goals that align with the CCAR. For instance, objective 2.2 states: "Rebalance the Asia-Pacific through enhanced diplomacy, security cooperation, and development." ${ }^{\text {86 }}$ Objective 2.3 is to "Prevent and respond to crises and conflict, tackle sources of fragility, and provide humanitarian assistance to those in need." ${ }^{87}$ Objective 3.1 advises that the Unites States will be "Building on strong domestic action, lead international actions to combat climate change." ${ }^{88}$ Finally objective 4.3 provides guidance to "Strengthen and protect civil society, recognizing the essential role of local capacity in advancing democratic governance and human rights.” ${ }^{89}$ With such clear guidance, and historical precedents for the US DoD to perform HA/DR, the next item to consider is where the US military should conduct those actions.

From a historical perspective, the United States has provided military capabilities and humanitarian assistance to many countries in the PACOM AOR. Since 2008, the United States has provided appreciable relief to the following Southeast Asia countries: Cyclone Nargis in Burma, 2008; the Padang Earthquake in Indonesia, 2009; the Monsoon Floods of Pakistan, 2010; the Great East Japan Earthquake of 2011; and Typhoon Haiyan in The Philippines, $2012 .{ }^{90}$ The two most significant countries on this list are The Philippines (with whom the United States has a long and close relationship) and Burma (despite the two countries having a frosty relationship).

${ }^{85}$ Ibid., 30.

${ }^{86}$ Ibid., 15.

${ }^{87}$ Ibid., 20.

${ }^{88}$ Ibid., 26.

${ }^{89}$ Ibid., 34.

90 Jennifer D. P. Moroney et al., Lessons from Department of Defense Disaster Relief Efforts in the Asia-Pacific Region (Santa Monica, CA: The RAND Corporation, 2013), xv- xvi. 
By providing assistance to two countries with such different forms of government, the United States has demonstrated its willingness to leverage DoD assets to provide immediate disaster relief.

Case Study in Doing HA/DR Wrong: Cyclone Nargis, Burma, 2008

While responding to Cyclone Nargis in Burma in 2008, the USG and DoD captured several best practices and identified areas of weakness. The Government Accountability Office (GAO) underscored the relief efforts in Burma as "less than optimal interagency coordination."91 A critical misstep early in the Cyclone Nargis relief efforts resulted from the perceived condemnation from then-First Lady Laura Bush of the Burmese government's failure to warn the population in time. This strategic communications effort ran counter to the narrative that the Joint Task Force (JTF) Caring Response tried to weave, which was that the United States was a trusted partner during the relief operations. Friction between the DoD and USAID resulted from divergent priorities and incongruent mission understandings. Specifically, the DoD viewed gaining access to the reclusive country as a strategic success and identified the number of C-130 relief flights allowed into the country as a metric of success. In contrast, USAID preferred to measure success in terms of what supplies were delivered. With preferences again diverging, the military opted to deliver supplies such as five gallon cans of water, maximizing the cargo capacity of the aircraft. USAID had argued that mosquito nets would be much more valuable, but the DoD disapproved because the nets were not dense enough to maximize lift capacity. On a more positive note, the GAO identified as a best practice the DoD maintaining all communications on the unclassified level, fostering effective interagency communication. ${ }^{92}$

\footnotetext{
${ }^{91}$ Ibid., 23.

${ }^{92}$ Moroney et. al, 23-24.
} 
The DoD did not deliver aid supplies to the Burmese people directly, but rather to the ruling military junta. This was a preventive action by the suspicious Burmese to lessen the visibility of foreign militaries operating in their country, but the implication was clear: even with substantial aid from foreign countries and the United Nations, the ruling junta still exercised coercive power over the population by controlling the distribution cycle. Preparatory HA/DR efforts during a future disaster must predict and mitigate the effects of as many points of friction as possible.

Case Study in Doing HA/DR Slightly Better: Typhoon Yolanda, the Philippines, 2013

Typhoon Yolanda, which struck Samar, the Philippines, on 7 November 2013, remains the most powerful storm on record. ${ }^{93}$ Travelling across nine of the country's 14 provinces, it impacted 14.1 million people, displaced 4.1 million, killed 6,201, and caused \$876,072,932 worth of damage. ${ }^{94}$ Yolanda relief efforts were successful and identify how the United States should establish control measures during Phase 0 of HA/DR operations. The challenges stemming from infrastructure damage were severe. The CFE-DMHA has outlined three areas where military assistance was necessary in the aftermath of Typhoon Yolanda: first, the heavy lift capability that the United States and other militaries provided to clear transportation routes and allow rescue workers to provide aid to affected locations; second, the military capability to provide aid to

\footnotetext{
${ }^{93}$ Center for Excellence in Disaster Management and Humanitarian Assistance, Lessons from Civil-Military Disaster Management and Humanitarian Response to Typhoon Haiyan (Yolanda) (Joint Base Pearl Harbor-Hickam, HI: Center for Excellence in Disaster Management and Humanitarian Assistance, January 2014), 9.

${ }^{94}$ Center for Excellence in Disaster Management and Humanitarian Assistance, Lessons from Civil-Military Disaster Management and Humanitarian Response to Typhoon Haiyan (Yolanda), 10, 11.
} 
remote areas; third, the military's ability to provide immediate relief to survivors as local governments mobilized to provide assistance. ${ }^{95}$

The strongest examples of intergovernmental, military-to-military cooperation during Typhoon Haiyan relief operations come from the cooperation of the Canadian military, Canadian Ministry of Foreign Affairs, and Filipino Governor of Capiz, Victor Tanco. The Ministry of Foreign affairs was proactive in creating an interdepartmental task force to balance relief efforts prior to Yolanda making landfall. The Canadians, both military and civilian Disaster Assistance Response Teams (DART), shared their command center with UN Office for the Coordination of Humanitarian Affairs (OCHA), the World Food Program (WFP), UNICEF, the Department of Safety and Security, and various NGOs, expediting information sharing. The information sharing included real-time satellite imagery provided by the Canadian military, which provided accurate and timely needs assessments. The Canadians also incorporated local liaison officers with Tagalog language skills to communicate the planned relief efforts, to "identify underserved communities and ensure duplication of efforts was limited."96 Positive working relationships among key decision-makers improved the efficiency of this command post. Senior decisionmakers had trained and deployed together previously. ${ }^{97}$

A network of trusted working relationships across militaries, governments, NGOs, and United Nations bodies, forged during Phase 0, amplified the efficiency of coordinated relief efforts. In the most recent after action review (AAR) of the Yolanda response, the CFE-DMHA stated: "The informal professional networks among relief workers built during common training

\footnotetext{
${ }^{95}$ Ibid.

${ }^{96}$ Center for Excellence in Disaster Management and Humanitarian Assistance, Lessons from Civil-Military Disaster Management and Humanitarian Response to Typhoon Haiyan (Yolanda), 28.

${ }^{97}$ Ibid., 30, 34.
} 
and exercises greatly facilitated the trust needed for effective and efficient cooperation, particularly in the early response phase.”98

The CFE-DMHA recorded six major lessons learned in its February 2015 review of Typhoon Haiyan. Two of those lessons presuppose bilateral pre-disaster preparedness. The first lesson, "Immediate Request for Assistance and Forward Deployed Assets Saved Lives,” emphasizes the timelines with which PACOM reacted to the typhoon, and recognizes the importance of Joint US Military Assistance Group and representatives from USAID and OFDA pre-positioning on the archipelago days before the typhoon made landfall. ${ }^{99}$ Lesson 4 , "Establishment of the International Coordination Team (ICT) Synchronized Effective International Support Through All Phases of USPACOM Operations,” demonstrates the need for a dedicated team to conduct regular assessments of the types of humanitarian aid the US military will likely be asked to provide in PACOM. ${ }^{100}$ The ICT meets twice yearly during Phase 0 and daily during a crisis. It includes representatives from the PACOM planning staff; LNOs from allied Pacific nations, including Japan, the Philippines, Canada, and Australia; and members of the OFDA staff. ${ }^{101}$ This central clearing house for pre-crisis planning and mid-crisis execution reduces response inefficiencies and establishes working relationships among necessary actors.

The Typhoon Yolanda relief effort was less successful in managing strategic communications, particularly the use of the media. This resulted in both imbalanced application

${ }^{98}$ Center for Excellence in Disaster Management and Humanitarian Assistance, An Inside Look into USPACOM Response to Super Typhoon Haiyan. (Joint Base Pearl Harbor-Hickam, HI, February 2015), 3.

${ }^{99}$ Ibid., 7.

${ }^{100}$ Center for Excellence in Disaster Management and Humanitarian Assistance, An Inside Look into USPACOM Response to Super Typhoon Haiyan, 9.

${ }^{101}$ Ibid. 
of limited resources (criticism that disproportionate media coverage in Tacloban diverted too many relief assets there) and undermined the goodwill the United States sought to establish. The overwhelmingly positive media coverage of US relief efforts played well to an only to an American audience. ${ }^{102}$ The news reports emphasizing American assistance delegitimized the Philippine government: they implied to the Filipino people their government could not effectively respond to the disaster. In an error of omission, the media did not report several major contributions that the Armed Forces of the Philippines (AFP) made in the more rural regions or their significant contributions in the beginning of the relief effort. Equally important, the AFP repaired runways in anticipation of $\mathrm{C} 130$ relief flights. The media tended to stay closer to the cities, and western media was not yet present to witness of the AFP's preparatory work. ${ }^{103}$

Finally, beyond the legal, doctrinal, and historical basis for HA/DR, the US Congress in 1994 created the CFE-DMHA. The CFE-DMHA's mission is to “Facilitate collaborative partnerships, conduct applied research, and develop education, training and information sharing programs in order to enhance US and international civil-military preparedness, knowledge, and performance in disaster management and humanitarian assistance pursuant to Title 10 U.S.C. section 182.” ${ }^{104}$ Currently commanded by Colonel Joseph D. Martin, the CFE-DHMA houses the institutional knowledge for the DoD on pre-crisis preparedness. ${ }^{105}$ The 2001 assignment of the

${ }^{102}$ Center for Excellence in Disaster Management and Humanitarian Assistance, Lessons from Civil-Military Disaster Management and Humanitarian Response to Typhoon Haiyan (Yolanda), 27.

103 Ibid., 25 -26.

${ }^{104}$ Center for Excellence in Disaster Management and Humanitarian Assistance, Strategy FY14-18, 1.

${ }^{105}$ Center for Excellence in Disaster Management and Humanitarian Assistance, “Colonel Joseph D. Martin,” accessed 26 February 2015, http://www.coe-dmha.org/about-cfedmha/staff/colonel-martin-joseph-d.html. 
CFE-DMHA as a direct reporting unit to PACOM, and concurrent authority to perform pre-crisis preparations in support of PACOM, indicates the priority senior national leaders place on crisis mitigation and disaster management within the PACOM AOR. ${ }^{106}$

The Center has working relationships with several sub-unified commands, other governmental agencies, institutions of higher education and international organizations. The CFEDMHA maintains a working relationship with the ASEAN. Two of the CFE-DMHA's primary goals underscore international cooperation for pre-crisis preparedness: first, serving as a clearinghouse for disaster management best practices, education, and training; second, providing subject matter expertise to joint task forces during HA/DR operations. ${ }^{107}$

Addressing These Challenges Efficiently: HA/DR Preparation in the Philippines

Pre-disaster preparedness in the PACOM AOR provides the United States an ideal opportunity to foster political goodwill with its allies. The most appropriate country, for geographic, economic, and historical reasons, is the Philippines. War theoretician Carl von Clausewitz wrote in his seminal work, On War, that shaping the pre-conflict phase "increase[s] the likelihood of success without defeating the enemy's forces. I refer to operations that have direct political repercussions, that are designed in the first place to disrupt the opposing alliance, or to paralyze it, that gains us new allies, favorably affect the political scene, etc.”108

The security of the Philippines is strategically significant to the United States, both economically and militarily. The 7,000 islands of the Philippines are strategically located between

${ }^{106}$ Center for Excellence in Disaster Management and Humanitarian Assistance, Strategy FY14-18, 1.

${ }^{107}$ Ibid., 4.

${ }^{108}$ Carl Von Clausewitz, On War, ed. Michael Howard, trans.Peter Paret (Princeton, NJ: Princeton University Press, 1989), 92. Emphasis Added. 
Northeast and Southeast Asia and connect Pacific Ocean to the South China Sea. Approximately half of the world's shipping tonnage, as well as 80 percent of crude oil shipments headed to Japan and South Korea, pass through the oceanic corridor and, for most of the 1900s, the Philippines has served as a logistics node for the US military. ${ }^{109}$ The United States would be a stakeholder in any Pacific conflict, but it is impossible to predict what US forces will be available or what competing priorities the DoD will have in the event of a future conflict. Therefore, the United States must build and maintain mutual trust with the government, the military, and the people of the Philippines now, during Phase 0 operations.

The Philippines will likely be receptive to the idea of bilateral cooperation in future natural disasters, as evidenced by the Fourth Philippines-United States Bilateral Strategic Dialogue. The Fourth Philippines-United States Bilateral Strategic Dialogue, held 6 and 7 March 2014 in Washington, DC, “continued the two allies’ close consultation and exchange of views on a broad range of bilateral, regional, and global issues that reflect common values, mutual respect, and converging interests.” ${ }^{110}$ This sentiment is codified by a 2011 treaty, the Manila Declaration, which stated "We are determined to continue our bilateral cooperation in addressing broader regional and global challenges, including maritime security and threats to security such as climate change." 111 During the response to Typhoon Haiyan, the Filipino people reacted positively to the

${ }^{109}$ Jim Thomas and Harry Foster, “The Geostrategic Return of the Philippines” (Center for Strategic and Budgetary Assessments, April, 2012), accessed 8 September 2014, http://www.csbaonline.org/publications/2012/04/the-geostrategic-return-of-the-philippines/.

${ }^{110}$ U.S. Department of State, "The Fourth Philippines-United States Bilateral Strategic Dialogue” (Washington, DC, 6-7 March 2014), accessed 1 December 2014, http://www.state.gov/r/pa/prs/ps/2014/03/223151.htm.

${ }^{111}$ Manila Declaration on U.S.-Philippine Alliance, 16 November 2011. 
United States performing disaster relief. ${ }^{112}$ More importantly, this relief effort demonstrated the cooperation that can occur among several allied nations during times of crisis. In response to Typhoon Haiyan, 57 other nations provided some level of disaster relief, with 29 committing military assistance. ${ }^{113}$

The United States has maintained a presence in the Philippines since 1898. Pursuant to article 3 of the Treaty of Paris, signed on 10 December 1898, Spain ceded sovereignty of the Philippines to the United States. ${ }^{114}$ The Senate ratified the treaty in February of 1899 and the documents of ratification were exchanged on 11 April, 1899. This lengthy transition established antecedent conditions that enabled an insurgency. The aims of the United States and the Filipino guerillas diverged as the insurgents demanded self-determination following years of mistreatment under the Spanish.

The roots of the insurgency had been planted years before. During their rule, the Spanish had recognized the traditional Filipino ruling class (principalia) as the local legal authority, allowing Filipino people to exercise control of their colony in return for the principalia's submission to Spanish rule. ${ }^{115}$ Though the system initially reflected the natural social order, tensions between the local principalia and Spanish immigrants intensified when the archipelago

112 Richard Javad Heydararian, "Strategic opportunity in Philippine crisis,” Asia Times, 21 November 2013, accessed 1 December 2014, http://www.atimes.com/atimes/Southeast_Asia/ SEA-02-211113.html.

${ }^{113}$ Center for Excellence in Disaster Management and Humanitarian Assistance, An Inside Look into USPACOM Response to Super Typhoon Haiyan, 5.

114 Treaty of Peace Between the United States and Spain, 10 December 1898, US Statutes at Large, 30, pt. 1754.

${ }^{115}$ Brian McAllister Linn, The U.S. Army and Counterinsurgency in the Philippine War, 1899-1902 (Chapel Hill: University of North Carolina Press, 1989), 3. 
began to export more agricultural goods. ${ }^{116}$ The tensions morphed into a nationalist movement, originally against the Spanish, which advocated liberalism, escalating into a full-scale rebellion in 1896. ${ }^{117}$ Within two years, Filipino leader Emilio Aguinaldo held the de facto leadership role among the Filipino fighters across the archipelago, despite his living temporarily in exile. ${ }^{118}$ When Admiral Dewey brought Aguinaldo back to Manila from Hong Kong, the morale of the Filipino nationalists increased and they soon defeated the remaining Spanish. Aguinaldo and Dewey maintained a friendly relationship, and Dewey did not object when Aguinaldo declared himself ruler of the Philippines. ${ }^{119}$ Nevertheless, the people of the Philippines and the government of the United States had different interpretations of the meaning of the Spanish surrender.

On 2 May 1898, President William McKinley directed Army forces to deploy to the Philippines. ${ }^{120}$ The President ordered Major General Wesley Merritt to remove all vestiges of Spanish power and influence. ${ }^{121}$ Governor General Arthur MacArthur, the father of WWII legend Douglas MacArthur, prophetically warned the McKinley administration that the Filipino people disliked the American army and supported the insurrection. ${ }^{122}$ From 4 February 1899, when
${ }^{116}$ Ibid.
${ }^{117}$ Ibid., 4.
${ }^{118}$ Ibid., 8.
${ }^{119}$ Ibid., 6.
${ }^{120}$ Ibid., 1.
${ }^{121}$ Center for Military History: United States Army, Correspondence Relating to the War With Spain And The Conditions Growing Out Of The Same Including The Insurrection In The Philippine Islands And The China Relief Expedition, Between The Adjutant General Of The Army And Military Commanders In The United States, Cuba, Porto Rico, China, And The Philippine Islands, From April 151898 to July 301902 (Washington, DC: Government Printing Office, 1993), 2:676. 571.

${ }^{122}$ Margaret Leech, In The Days of McKinley (New York: Harper and Brothers, 1959), 
Private William Grayson opened fire on a Filipino patrol that did not provide a password to answer his challenge, through 4 July 1902, the US Army fought the Filipino nationalist army. ${ }^{123}$

Even after the initiation of hostilities, President McKinley acknowledged the importance of the United States maintaining legitimacy in the eyes of the Filipino people. He stated: "It should be the earnest and paramount aim of the military administration to win the confidence, respect, and admiration of the inhabitants of the Philippines by assuring them in every possible way that full measure of individual rights and liberties which is the heritage of free peoples, and by proving to them that the mission of the United States is one of benevolent assimilation, substituting the mild sway of justice and right for arbitrary rule.”124

Only after a series of grisly campaigns, including the large-scale destruction of food stores, did the starving Filipino guerillas finally surrendered on 16 April $1902 .{ }^{125}$ The atrocious nature of these campaigns resulted in wide-ranging property damage and human rights violations, including torture and murder perpetrated by the US Army. By the spring of 1901, however, the US Supreme Court clarified the status of the people of the Philippines in a series of unrelated court cases, declaring that they had the same civil rights as Americans but were not citizens. ${ }^{126}$ Given such an initially disadvantageous starting point, it is particularly impressive that two countries have cultivated such a powerful, long-term relationship that endured even following Philippine independence. Indeed, since 1899, and with only a brief break beginning in December 1941, the United States has maintained a military presence in the Philippines.

${ }^{123}$ Linn, The U.S. Army and Counterinsurgency in the Philippine War, 1899-1902, 12.

${ }^{124}$ Center for Military History: United States Army, 2:859.

${ }^{125}$ Brian McAllister Linn, The Philippine War (Lawrence: University Press of Kansas, 2000), 304.

${ }^{126}$ H. Wayne Morgan, William McKinley and His America (Syracuse: Syracuse University Press, 1963), 444. 
During World War II, the strategic importance of Leyte, one of the Visayan Islands, became obvious. Situated in middle of the Philippine island chain, Leyte’s seizure in 1941 disadvantaged the US military by prohibiting use of a SLOC, restricting basing capabilities, and curtailing operational reach. In October 1944, the United States recaptured Leyte. This secured basing and eventually facilitated the recapture of Philippine islands still under Japanese occupation, by expanding operational reach and increasing the tempo of operations in the Pacific due to more efficient lines of communications. ${ }^{127}$ Conversely, the US liberation of the Philippines placed the Japanese military at an operational disadvantage by denying the Imperial Japanese Navy use of the SLOCs, basing capabilities, and by isolating the home islands from the Southern Resources Area (SRA). As evidenced by World War II operations, the SLOCs location adjacent to the Philippines, as well as the basing afforded by the islands, granted the United States an operational advantage in the pacific region.

The 17 million Filipinos remained loyal to the United States as they suffered horrendous abuses at the hands of the Japanese. ${ }^{128}$ Liberating the Filipinos created a powerful strategic communications narrative in the region: the United States values the human rights of all people and the right to self-determination for all governments. Though the United States is no longer at war with Japan, the availability of basing and lengthened lines of communications provided by the alliance with the Philippines remains a combat multiplier in the PACOM AOR. The nature of the US military presence in the Philippines has evolved over the past century, from permanent garrisons early in the relationship to the temporary, cyclic presence today characterized by annual exercises such as Balikatan, but the two nations’ historical and military bonds remain robust.

${ }^{127}$ Milan N. Vego, Operational Warfare: Theory and Practice (Newport: U.S. Naval War College Press, 2007), II-13.

${ }^{128}$ A. V. H. Hartendorp, The Japanese Occupation of the Philippines, Volume 1 (Makati: MDP Printing, 1967), 444-507. 
Beyond the unique historical relationship between the United States and the Philippines, the Philippines government has taken proactive measures to mitigate potential harm caused by natural disasters. For instance, it has a minimal carbon footprint and emphasizes the use of biofuels. Yet these efforts are insufficient to insulate the island nation from climate changeinduced natural disasters. ${ }^{129}$ The Economic and Environment program for Southeast Asia has determined that the Philippines is at a high vulnerability for floods, tropical cyclones, and sea level rise. ${ }^{130}$ In response, the Philippine government combats both deforestation and unemployment by upgrading select farmland to integrated rice production land. ${ }^{131}$ Despite these efforts by the government, the Philippines remains at risk during times of resource scarcity. Historically, the wealthiest and most influential 10 to 20 percent of the citizens have control over half of the nations' wealth. As a result, Filipinos will naturally cooperate more readily within smaller groups and engage in greater competition among different groups. This cultural norm predisposes the Filipinos to compound the impacts of resource scarcity because the groups will likely compete against one other for limited resources. ${ }^{132}$ To mitigate any such hoarding of scarce resources during an environmental emergency, it is vital that the United States and the Philippines have a well-rehearsed disaster mitigation plan in place. In the long term, it is likely that the Filipinos will contend with both rising sea levels and acidification of the ocean. The acidification of the oceans will likely have a deleterious effect on fisheries, increasing the potential for food

${ }^{129}$ Webersik, 109.

${ }^{130}$ Arief Anshory Yusuf and Herminia A. Francisco, "Climate Vulnerability Mapping for Southeast Asia” (Economy and Environment Program for Southeast Asia, January 2009), 6, accessed 3 October 2014, http://www.idrc.ca/uploads/user-S/12324196651Mapping_Report.pdf.

131 Stern, 609.

132 Richard J. Kessler, Rebellion and Repression in the Philippines (New Haven: Yale University Press, 1989), 18. 
scarcity, which is another contributor to large scale, unplanned migration. Specifically, the increased carbon in the water impedes the formation of both shells and skeletons for sea life, slowing or stopping the growth of corals needed as a home for fish in commercial fisheries and reducing the plankton and sea snails at the bottom of the food chain. Commercially raised fish and, in particular, mackerel and salmon, would be directly impacted. ${ }^{133}$ The smaller islands of the Philippines will feel the impact of rising sea levels more so than the larger, and when combined with food scarcity, the potential exists for mass, unplanned migration either internally or externally. ${ }^{134}$

Just as IS exploited water resources in Fallujah and Mosul, there are several violent extremist groups in the Philippines that could potentially leverage water or food scarcity to wield coercive influence. The DoS identifies several non-state armed groups conducting terrorism and violent extremism in the Philippines. The most active and influential groups are the New People’s Army (NPA), the Abu Sayyaf Group, and the Jemaah Islamiya. The Philippine government identifies the 5,000-strong NPA as the most powerful terrorist group and as its greatest internal security threat. Their stated goal is to supplant the legitimate government of the Philippines using protracted, guerilla warfare, eventually installing a Maoist regime. To this end, they’ve conducted coordinated acts of sabotage against three mining facilities and destroyed \$68 million worth of equipment and infrastructure. The NPA engages in illegal taxation and extortion to fund their operations, and could opportunistically use a natural disaster as a point of entry to further their own influence. ${ }^{135}$

\footnotetext{
${ }^{133}$ Stern, 86.

${ }^{134}$ Ibid., 65-68.

${ }^{135}$ Republic of the Philippines, National Security Council, National Security Policy, 2011-2016 (Manilla: Office of the President/ National Security Council, 2010), 15.
} 
The ASG's base is uneducated, poor youth and though they are comparatively small they wield significant influence. They successfully networked with other armed groups in Mindanao to include those that engage in partisan political acts. ${ }^{136}$ Humanitarian shortfalls following a natural disaster could empower the ASG, as the support they receive comes largely from a perception of ineffective government, conflict among ethnic groups, and poverty. Improper, slow, or inefficient response to disaster could exacerbate these conditions.

Beyond these groups, there are numerous emerging organizations that pose a threat to Philippine national security, ranging from the "lost commands” of the Moro Islamic Liberation Front to the Bangsamoro Islamic Freedom Movement, the Moro National Liberation Front, the $\mathrm{Al}$ Khobar Group, the Awliya Group of Freedom Fighters, the Khilafa Islamiya, and the Moro Army Committee. ${ }^{137}$ If the Philippine government is not able to react quickly to a natural disaster and provide required humanitarian assistance to affected areas, these armed groups could exploit the seam. Results could range from the inability of aid workers to quickly delivery needed supplied to areas of the country to a change in government of the Philippines, upsetting the regional balance of power. Such a change in government could also potentially deny the DoD the basing opportunities and SLOCs previously identified as necessary for an effective, timely response in the event of Chinese aggression, a DPRK invasion of South Korea, or the six-nation territorial dispute in the South China Sea escalating into a shooting war. It is imperative that the government of the Philippines continue to enjoy the popular support of its people as a hedge against potential insurgent groups, and a very visible way for the government to continue to

${ }^{136}$ Rommel C. Banlaoi, “Current Terrorist Groups and Emerging Extremist Armed Movements in the Southern Philippines," Threats to Philippine National Security, 168, accessed 26 February 2015, http://www.ndcp.edu.ph/for\%20NDCP\%20website/BANLAOI_ Current\%20Terrorist\%20Groups\%20and\%20Emerging\%20Extremist\%20Armed\%20Movement \%20in\%20the\%20Southern\%20Philippines\%20Threats\%20to\%20Philippine\%20National\%20Se curity.pdf.

${ }^{137}$ Banlaoi, 166-171. 
demonstrate its competence to the people is by effective, timely responses to environmental crises.

Armed with these data, it is appropriate to consider what natural disasters are most likely to occur in the Philippines, and what specific HA/DR will be required to address humanitarian crises. Looking at recent trends through the lens of climate science, a typhoon is the disaster most likely to occur in the Philippines. The ancillary disasters that are likely to accompany a typhoon, such as flooding and mudslides, further complicate rescue efforts and compound suffering. ${ }^{138}$

The United States government should caution against unintentionally creating a narrative that the host nation is incapable of addressing the needs of its people, thus unintentionally delegitimizing the government and robbing it of sovereignty. Fortunately, the AFP is modernizing. Pursuant to Republic Act 10349, the Philippines government has allocated 173 million dollars toward modernization prior to $2018 .{ }^{139}$ Interagency communication and information sharing are institutional challenges that can be addressed directly during joint USPhilippines HA/DR response exercises. The RAND Corporation studied the response to several natural disasters in the Asia-Pacific region and reported that the efficiency with which agencies communicated with one another was directly related to the strength of their pre-existing relationships. ${ }^{140}$ The CFE-DMHA report, “Lessons from Typhoon Haiyan,” corroborated the RAND corporations’ assessment. ${ }^{141}$

${ }^{138}$ Anshory and Francisco, 6,

${ }^{139}$ Congress of the Philippines, Republic Act 10349. 15th Cong., 3rd sess. 23 July 2012, 5.

${ }^{140}$ Moroney et al., 18.

${ }^{141}$ Center for Excellence in Disaster Management and Humanitarian Assistance, Lessons from Civil-Military Disaster Management and Humanitarian Response to Typhoon Haiyan (Yolanda). , 15. 
While responsive, sufficient HA/DR following a typhoon in the Philippines will not necessarily degrade the ability of a local extremist group to undermine the Philippine government, the lack of essential services or the perception that the Philippine government is unable to care for its people following a disaster could provide an opportunity for one of these groups to strike, as noted above by Homer-Dixon and Briggs. Violent extremist groups, subscribing to a broad spectrum of harmful ideologies and motivated by an equally diverse series of goals and desires, can introduce destabilizing ambiguity into the country during environmental crises. The 2008 NDS makes particular note of the damage to regional stability that an extremist group can cause. The NDS notes a series of effects caused by these actors, including human trafficking, drug export, terrorism, and illegal arms trade. As a control measure to prevent these from occurring, the NDS states that the US policy is to "build internal capacities of countries at risk.” ${ }^{142} \mathrm{HA} / \mathrm{DR}$ provides such as pathway for building these capabilities.

\section{Conclusion}

The United States will realize tangible benefits by performing bilateral HA/DR preparation with the Philippines, and there is both legal justification and national historical precedent for doing so. The United States can expand on the US-Philippine trust that began with liberating the islands from Japanese control in World War II and continued during relief efforts to Typhoon Yolanda by performing the preparation exercises. The ability to react to a military development in the PACOM AOR maximizing the basing capabilities and lines of communications provided by the Philippines is strengthened by the relationship-building during the pre-crisis phase.

${ }^{142}$ Department of Defense, 2008 National Defense Strategy (Washington, DC, June 2008), 9, accessed 28 February 2015, http://www.defense.gov/news/2008\%20National\%20Defense\%20Strategy.pdf. 
The United States simply cannot afford to adopt a reactive posture to a potential crisis in PACOM. The geographic separation between mainland United States and potential battlegrounds in the Pacific is so great that access to basing and lines of communications will be absolutely critical. Having identified potential military and non-military threats as well as armed non-state groups in the region, the $\mathrm{DoD}$ can approximate the type of crisis it may have to respond to. It is axiomatic that trust among countries and between decision makers develops over time. It is also axiomatic that an intimate familiarity with the culture and terrain of an area where the military will be performing operations is a tremendous benefit. Given the fact that climate change is happening and results of climate change in PACOM range from sudden onset natural disasters such as typhoons to longer developing crises such as population migration, the United States can exploit the opportunity provided by strengthening strong military-to-military partnerships via the provision of HA/DR. These relationships and mutual trust mature over time as a result of a continued positive working relationship. PACOM covers a huge piece of the earth with many competing actors and interests, and the United States cannot address all contingencies in light of the current fiscal realities. The Philippines, a historical ally, is strategically important due to both geography and treaties, and is also prone to natural disaster. The United States should build good faith with the Philippines by conducting military to military bilateral preparations to react to natural disasters in the Philippines and civilian to civilian relationships by having the DoS and USAID coordinate with the government of the Philippines. To ensure success, however, the United States must carefully manage strategic communications so that the narrative underscores the accomplishments and competencies of the Philippine government.

Clumsy strategic communications occurred during Cyclone Nargis and Typhoon Yolanda. In both cases, the desired narrative addressed only a single audience without due consideration to other audiences' reaction to that message. A critical aspect of Phase 0 planning must be management of the content and intended audience (and their anticipated reaction) 
strategic communication. Of particular importance is emphasizing to host nation's citizenry the significant impact of the contributions that their own military, government or volunteer organizations. To ensure that these contributions are properly recognized, public affairs officers and media relations personnel must be cognizant of the geographic areas where indigenous personnel are performing relief efforts and ensure that print and broadcast media have access to those locations, recognizing that the media may require physical assistance to get there (if, for example, the rural areas are inaccessible to civilian traffic due to roads or bridges being nontrafficable). Second, public statements by leaders need to focus on cooperation among nations and with non-governmental organizations. Finally, though the government of the Philippines is a democracy friendly to the United States, it has been noted previously that culturally they are more predisposed to cooperate within smaller groups (as opposed to larger groups). This also serves as a warning that any of the identified violent non-state actors operating in the Philippines could increase their local influence by attempting to control supply distribution.

It is imprudent to wait until a crisis develops before negotiating with the Philippine government for basing rights and the subsequent operational reach and improved operational tempo those basing rights will provide. Rather, the United States must deliberately and earnestly build trust now, prior to a future crisis. To both build this trust and to become familiar with the people, geography, and hydrology of the Philippines, the US Government, with the government of the Philippine's cooperation, should launch preparations to react to the events of a natural disaster. In concert with international organizations (IGOs) and non-governmental organizations (NGOs), the collective effort will better prepare all parties to provide timely, efficient, and appropriate HA/DR. Again revisiting the liberal realist worldview espoused by Joseph Nye, this preparation and potential reaction to a natural disaster nests cleanly with the objective of a liberal 
realist strategy: security for the United States and her allies, mitigating environmental disasters, and encouraging liberal democracy abroad. ${ }^{143}$

143 Nye, 231. 


\section{Bibliography}

Acharya, Amitav. Promoting Human Security: Ethical, Normative and Educational Frameworks in Southeast Asia. Paris, France: UNESCO, 2007.

Adger, W. Neil, P. Mick Kelly, and Nguyen Huu Ninh, eds. Living with Environmental Change: Social Vulnerability, Adaptation and Resilience in Vietnam. New York: Routledge, 2001.

Al- Rubaye, Ahmed. “Islamic State Seizes Iraq’s Largest Dam.” Aljazeera America, 7 August 2014. Accessed 25 February 2015. http://america.aljazeera.com/articles/2014/8/7/iraqimilitants-seizecountryslargestdam.html.

Anbumozhi, Venkatachalam, Meinhard Breiling, Selvarajah Pathmarajah, and Vangimalla R. Reddy. Climate Change in Asia and the Pacific: How Can Countries Adapt? Thousand Oaks, CA: Sage Publications, 2012.

Army Science Board. Planning for Climate Change: Actions for the Army to Better Adapt to the Effects of Climate Change in 2030. Washington, DC: Department of the Army, November 2013.

Asia Development Bank. Addressing Climate Change and Migration in Asia and the Pacific. Mandaluyong City, Philippines: Asian Development Bank, 2012.

Association of South East Asian Nations. ASEAN Agreement on Disaster Management and Emergency Response. Vientiane 2005. Accessed 3 December 2014. http://www.asean.org/communities/asean-socio-cultural-community/item/the-aseanagreement-on-disaster-management-and-emergency-response.

- The ASEAN Charter. Jakarta: ASEAN Secretariat, 2008. Accessed 18 January 2015. http://www.asean.org/archive/publications/ASEAN-Charter.pdf.

Banlaoi, Rommel C. "Current Terrorist Groups and Emerging Extremist Armed Movements in the Southern Philippines.” Threats to Philippine National Security: 163-181. Accessed 26 February 2015. http://www.ndcp.edu.ph/for\%20NDCP\%20website/

BANLAOI_Current\%20Terrorist\%20Groups\%20and\%20Emerging\%20Extremist\%20Ar med\%20Movement\%20in\%20the\%20Southern\%20Philippines\%20Threats\%20to\%20Phi lippine\%20National\%20Security.pdf.

Berger, John J. Climate Peril: The Intelligent Reader's Guide to Understanding the Climate Crisis. Berkeley, CA: Northbrae Books, 2014.

Briggs, Chad M. "Environmental Change, Strategic Foresight, and Impacts on Military Power.” Parameters 40, no. 3 (Autumn 2010): 1-15.

Bruner, Ken M. “Soft Power and Its Use in the Asia Pacific Region.” US PACOM Science and Technology, June 2011. Accessed 30 August 2014. http://www.dtic.mil/ ndia/2011SET/Bruner.pdf.

Center for Excellence in Disaster Management and Humanitarian Assistance. An Inside Look into USPACOM Response to Super Typhoon Haiyan. Joint Base Pearl Harbor-Hickam, HI: 
Center for Excellence in Disaster Management and Humanitarian Assistance, February 2015.

. “Colonel Joseph D. Martin.” Accessed 26 February 2015. http://www.coe-dmha.org/ about-cfe-dmha/staff/colonel-martin-joseph-d.html.

- Lessons from Civil-Military Disaster Management and Humanitarian Response to Typhoon Haiyan (Yolanda). Joint Base Pearl Harbor-Hickam, HI: Center for Excellence in Disaster Management and Humanitarian Assistance, January 2014.

- Strategy FY14-18. Joint Base Pearl Harbor-Hickam, HI: Center for Excellence in Disaster Management and Humanitarian Assistance, January 2014. Accessed 26 February 2015. https://www.cfedmha.org/LinkClick.aspx?fileticket=Y_TPmmK5_b8\%3d\&portalid=0.

Center for Military History: United States Army. Correspondence Relating to the War With Spain And The Conditions Growing Out Of The Same Including The Insurrection In The Philippine Islands And The China Relief Expedition, Between The Adjutant General Of The Army And Military Commanders In The United States, Cuba, Porto Rico, China, And The Philippine Islands, From April 151898 to July 30 1902. 2 Vols. Washington, DC: Government Printing Office, 1993.

Chairman of the Joint Chiefs of Staff. Capstone Concept for Joint Operations: Version 3.0. Washington DC: Joint Chiefs Office, 2009.

Chase, Michael S. Jeffrey Engstrom, Tai Ming Cheung, Kristen Gunness, Scott Warren Harold, Susan Puska, and Samuel K. Berkowitz. China's Incomplete Military Transformation: Assessing the Weaknesses of the People's Liberation Army. Santa Monica, CA: Rand Corporation, February 2015.

“China Holds More US Debt than Indicated.” Washington Times, 2 March 2010. Accessed 26 February 2015. http://www.washingtontimes.com/news/2010/mar/2/chinas-debt-to-ustreasury-more-than-indicated/.

Clausewitz, Carl Von. On War. Edited by Michael Howard. Translated by Peter Paret. Princeton, NJ: Princeton University Press, 1989.

Clark, Ryan. “Chinese Energy Security: The Myth of the PLAN’s Frontline Status.” Letort Papers, U.S. Army War College, Strategic Studies Institute, Carlisle, PA, 2010.

CNA Corporation. National Security and the Threat of Climate Change. Alexandria, VA: CNA Corporation, 2008.

Congress of the Philippines. Republic Act 10349. 15th Cong., 3rd sess. 23 July 2012. Accessed 19 March 2015. http://www.pcoo.gov.ph/issuances/issuances-ra/RA-10349.pdf.

Cruz, Sherman O. "Possible Scenarios on the Future of the Panatag Shoal (Huangyan Island/ Scarbrough Shoal) Controversy using Jim Dator's Four Archetypes of Alternative Futures.” Journal of Future Studies 18, no. 2 (December 2013): 35-36. 
Davenport, Coral. "Pentagon Signals Security Risks of Climate Change.” The New York Times, 13 October 2014.

Department of Defense. 2008 National Defense Strategy. June 2008. Accessed 28 February 2015. http://www.defense.gov/news/2008\%20National\%20Defense\%20Strategy.pdf.

_ 2014 Climate Change Adaptation Roadmap. June 2014. Accessed 18 February 2015. http://www.acq.osd.mil/ie/download/CCARprint.pdf.

. 2014 Quadrennial Defense Review. Washington, DC: Government Printing Office, 2014.

. "Landon Lecture” (Kansas State University). Remarks as Delivered by Secretary of Defense Robert M. Gates, Manhattan, Kansas, 26 November 2007. Accessed 12 August 2014. http://www.defenselink.mil/speeches/speech.aspx?speechid=1199.

- Military and Security Developments Involving the Democratic People's Republic of Korea 2013 A Report to Congress Pursuant to the National Defense Authorization Act for Fiscal Year 2012. Washington, DC, 2013. Accessed 1 December 2014.

http://www.defense.gov/pubs/North_Korea_Military_Power_Report_2013-2014.pdf.

Dörner, Dietrich. The Logic of Failure: Recognizing and Avoiding Error in Complex Situations. New York: Basic Books, 1996.

Elleman, Bruce A. Waves of Hope: The U.S. Navy's Response to the Tsunami in Northern Indonesia. Newport, RI: Naval War College Press, 2007.

Fingar, Thomas. Global Trends 2025: A Transformed World. Washington, DC: National Intelligence Council, 2008.

Hartendorp, A. V. H. The Japanese Occupation of the Philippines, Volume 1. Makati: MDP Printing, 1967.

Hauger, J. Scott, Ph.D. "Climate Change Challenges for the Pacific Islands Region and Opportunities and Mechanisms for Cooperation.” Powerpoint Presentation, 5 August 2014.

Heydararian, Richard Javad. "Strategic opportunity in Philippine crisis.” Asia Times, 21 November 2013. http://www.atimes.com/atimes/Southeast_Asia/SEA-02-211113.html.

Holland, Paula. “Statistical Summary: Hydrometeorological Disasters in the Pacific.” SPC SOPAC Published Report (PR187), 2014. Accessed 25 February 2015. http://www.wmo.int/sids/sites/default/files/Statistical\%20Summary\%20\%20Hydrometeorological\%20Disasters\%20in\%20the\%20Pacific.pdf.

Homer-Dixon, Thomas. “Biography,” Thomas Homer-Dixon professional website. Accessed 18 January 2015. http://www.homerdixon.com/biography/.

- “The Ingenuity gap: Can Poor Countries Adapt to Resource Scarcity?” Population and Development Review 21, no. 3 (September 1995): 587-612. 
Intergovernmental Panel on Climate Change. Climate Change 2007: Impacts, Adaptation and Vulnerability. New York: Cambridge University Press, 2007. Accessed 25 February 2015. http://www.ipcc.ch/publications_and_data/publications_ipcc_fourth_ assessment_report_wg2_report_impacts_adaptation_and_vulnerability.htm.

“Climate Change 2013: The Physical Science Basis.” IPCC, September 2013. Accessed 30 August 2014. http://www.climatechange2013.org/report/.

- Managing the Risks of Extreme Events and Disasters to Advance Climate Change Adaptation. New York: Cambridge, 2012.

—_. “Organization.” Accessed 3 October 2014. http://www.ipcc.ch/organization/ organization.shtml.

. Intergovernmental Panel on Climate Change, 2014: Summary for Policymakers. In: "Climate Change 2014: Impacts, Adaptation, and Vulnerability." Contribution of Working Group II to the Fifth Assessment Report of the Intergovernmental Panel on Climate Change (Cambridge, United Kingdom and New York, USA, 2014).

International Strategy for Disaster Reduction. "Hyogo Framework for Action 2005-2015: Building the Resilience of Nations and Communities to Disasters.” United Nations International Strategy for Disaster Reduction, 2005. Accessed 30 August 2014. http://www.unisdr.org/.

International Red Cross and Red Crescent Movement. "Code of Conduct for Disaster Relief." Accessed 30 August 2014. http://www.ifrc.org/publicat/conduct.

Joint Chiefs of Staff. Joint Publication (JP) 3-16, Multi-National Operations. Washington, DC: Government Printing Office, 2013.

. Joint Publication (JP) 5-0, Joint Operational Planning. Washington, DC: Government Printing Office, 2011.

Jones, Bob. HA/DR: Recommendations for achieving the U.S. Navy's Expanded Core Capabilities in the PACOM AOR. Newport, RI: Naval War College Press, 2008.

Katzman, Kenneth Christopher M. Blanchard, Carla E. Humud, Rhoda Margesson, and Matthew C. Weed. The "Islamic State" Crisis and U.S. Policy. Washington, DC: Congressional Research Service, February 2015.

Keck, Zachary. “China Imposes Restrictions on Airspace Over Senkaku Islands.” The Diplomat, 23 November 2013. Accessed 19 February 2015. http://thediplomat.com/2013/11/chinaimposes-restrictions-on-air-space-over-senkaku-islands/.

Kessler, Richard J. Rebellion and Repression in the Philippines. New Haven: Yale University Press, 1989.

Laksmana, Evan A. "Climate Insecurities: Exploring the Strategic Implications for Asia-Pacific Armed Forces.” Asia Security Initiative Policy Series Working Paper Number 13, Centre for Strategic and International Studies, Jakarta, Indonesia, April 2011. 
Leech, Margaret. In The Days of McKinley. New York: Harper and Brothers, 1959.

Linn, Brian McAllister. The Philippine War: 1899-1902. Lawrence: University of Kansas Press, 2000.

The U.S. Army and Counterinsurgency in the Philippine War, 1899-1902. Chapel Hill:

The University of North Carolina Press, 1989.

Locklear, Samuel J. “Asia-Pacific Rebalance: Defending Shared Domains.” Conference of Defence Associations, Ottawa, Ontario, Canada, 21 February 2013. Accessed 2 August 2014. http://www.pacom.mil/Media/SpeechesTestimony/tabid/6706/Article/5275/asiapacific-rebalance-defending-the-shared-domains.aspx.

“Atlantic Council Roundtable.” PACOM, 6 March 2014. Accessed 2 August 2014. http://www.pacom.mil/Media/SpeechesTestimony/tabid/6706/Article/565158/atlanticcouncil-roundtable.aspx.

. “Press Briefing, Pentagon Briefing Room.” PACOM, 23 January 2014. Accessed 2 August 2014. http://www.pacom.mil/Media/SpeechesTestimony/tabid/6706/Article/ 565150/department-of-defense-press-briefing-by-admiral-locklear-in-the-pentagonbriefi.aspx.

"Press Conference, East Asia Pacific Media Hub.” PACOM, 5 February 2014. Accessed 26 February 2015. http://www.pacom.mil/Media/SpeechesTestimony/tabid/6706/Article/ 565152/adm-samuel-j-locklear-media-availability.aspx.

“News Briefing, Pentagon Briefing Room.” PACOM, 6 December 2012. Accessed 2 August 2014. http://www.pacom.mil/Media/SpeechesTestimony/tabid/6706/Article/ 565148/a-combatant-commanders-view-on-the-asia-pacific-rebalance-the-patch-workquilt.aspx.

"PACOM Senate Armed Services Committee Posture Statement.” PACOM, 25 March 2014. Accessed 2 August 2014. http://www.pacom.mil/Media/SpeechesTestimony/ tabid/6706/Article/565154/pacom-senate-armed-services-committee-posturestatement.aspx.

"PACOM Senate Armed Services Committee Testimony.” PACOM, 25 March 2014. Accessed 2 August 2014. http://www.pacom.mil/Media/SpeechesTestimony/tabid/6706/ Article/565155/pacom-senate-armed-services-committee-testimony.aspx.

McGrady, Ed, Maria Kingsley, and Jessica Stewart. Climate Change: Potential Effects on Demands for US Military Humanitarian Assistance and Disaster Response. Alexandria, VA: CNA Analysis and Solutions, November 2010.

Manton, Michael, and Linda Anne Stevenson. Climate in Asia and the Pacific: Security, Society, and Sustainability. New York: Springer, 2014.

Mohammad, Layla. “All Gates of Fallujah Dam Open, Says Esawi.” Iraqi News, 13 April 2014. Accessed 25 February 2015. http://www.iraqinews.com/features/all-gates-of-fallujahdam-open-says-esawi/. 
Morgan, H. Wayne. William McKinley and His America. Syracuse: Syracuse University Press, 1963.

Moroney, Jennifer D. P., Stephanie Pezard, Laurel E. Miller, Jeffrey Engstrom, and Abby Doll. Lessons from Department of Defense Disaster Relief Efforts in the Asia-Pacific Region. Santa Monica, CA: The RAND Corporation, 2013.

Morrison, Wayne M., and Marc Labonte. China's Holdings of U.S. Securities: Implications for the U.S. Economy. Washington, DC: Congressional Research Service, 2008. Accessed 23 November 2014. http://fpc.state.gov/documents/organization/99496.pdf.

Nye, Joseph S. The Future of Power. New York: Public Affairs. 2011.

Obama, Barack. “Address Before a Joint Session of Congress on the State of the Union.” Code of Federal Regulations, title 3 (20 January 2015).

Republic of the Philippines, National Security Council. National Security Policy, 2011-2016. Manilla: Office of the President/ National Security Council, 2010. Accessed 19 March 2015. http://icto.dost.gov.ph/wp-content/uploads/2014/07/PH-National-SecurityPolicy_2011-2016.pdf.

O’brien, Karen, Asunción Lera St. Clair, and Berit Kristoffersen. Climate Change, Ethics, and Human Security. New York: Cambridge University Press, 2010.

Oxfam International. "From Weather Alert to Climate Alarm.” Oxfam Briefing Paper, November 2007. Accessed 2 August 2014. https://www.oxfam.org/sites/www.oxfam.org/ files/climate\%20alarm.pdf.

Parry, M. L., O. F. Canziani, J. P. Palutikof, P. J van der Linden, and C. E. Hanson, eds. Climate Change 2007: Impacts, Adaptation and Vulnerability. New York: Cambridge University Press, 2007. Accessed 25 February 2015. http://www.ipcc.ch/publications_and_data/ publications_ipcc_fourth_assessment_report_wg2_report_impacts_adaptation_and_vulne rability.htm.

Pumphrey, Carolyn. Global Climate Change: National Security Implications. Carlisle, PA: US Army War College Strategic Studies Institute Press, 2008.

Schoenhaus, Robert M. Training for Peace and Humanitarian Relief Operations: Advancing Best Practices. Washington, DC: United States Institute of Peace Press, 2002.

Scobell, Andrew. "Show of Force: The PLA and the 1995-1996 Taiwan Strait Crisis." Asia/Pacific Research Center, January 1999. Accessed 10 February 2015. http://iisdb.stanford.edu/pubs/10091/Scobell.pdf.

Stern, Nicholas. The Economics of Climate Change: The Stern Review. Cambridge: Cambridge University Press, 2007.

Treaty of Peace Between the United States and Spain, 10 December 1898, US Statutes at Large, 30, pt. 1754. 
Thomas, Jim, and Harry Foster. “The Geostrategic Return of the Philippines.” Center for Strategic and Budgetary Assessments. April 2012. Accessed 8 September 2014. http://www.csbaonline.org/publications/2012/04/the-geostrategic-return-of-thephilippines/.

Thomas, Vinod, Jose Ramon G. Albert, and Cameron Hepburn. "Contributors to the frequency of intense climate disasters in Asia-Pacific countries.” Springerlink.com, 2014. Accessed 1 December 2014. http://reliefweb.int/sites/reliefweb.int/files/resources/ Contributors\%20to\%20the\%20frequency\%20of\%20intense\%20climate\%20disasters\%20 in\%20Asia\%20Pacific\%20countries.pdf.

United States Marine Corps, Department of the Navy, United States Coast Guard. A Cooperative Strategy for $21^{\text {st }}$ Century Seapower. October 2007. Accessed 22 September 2014. http://www.navy.mil/maritime/MaritimeStrategy.pdf.

US Congress. Senate. To Express the Sense of the Senate that Climate Change is not a Hoax, 114th Cong, 1st sess. Congressional Record, vol. 161, daily ed. (21 January 2015), S. Amdt. 29 to S. Amdt. 2 to S1.

US Department of State. “Foreign Terrorist Organizations.” Accessed 29 January 2015. http://www.state.gov/j/ct/rls/other/des/123085.htm.

—. FY 2014-2017 U.S. Department of State-USAID Strategic Plan. Washington, DC: Department of State, 2014.

“Manila Declaration on U.S.-Philippine Alliance.” 16 November 2011. Accessed 22 September 2014. http://translations.state.gov/st/english/texttrans/2011/11/ 20111116141458su0.2878338.html\#axzz3D8h9TNPY.

_ . "The Fourth Philippines-United States Bilateral Strategic Dialogue.” Washington, DC, 67 March 2014. Accessed 1 November 2014. http://www.state.gov/r/ pa/prs/ps/2014/03/223151.htm.

US Energy Information Administration. World Oil Transit Chokepoints. November 2014. Accessed 25 February 2015. http://www.eia.gov/countries/analysisbriefs/ World_Oil_Transit_Chokepoints/wotc.pdf.

US Pacific Command. “USPACOM Area of Responsibility.” Accessed 26 February 2015. http://www.pacom.mil/AboutUSPACOM/USPACOMAreaofResponsibility.aspx.

US-China Economic and Security Review Commission. 2013 Report to Congress. Washington, DC: Government Printing Office, 2013. Accessed 6 December 2014. http://www.uscc.gov/Annual_Reports/2013-annual-report-congress.

Vego, Milan N. Operational Warfare: Theory and Practice. Newport, RI: U.S. Naval War College Press, 2007.

Victor, David G. Climate Change: Debating America’s Policy Options. New York: Brookings Institute Press, 2004. 
Wan, William. “As Budgets Soar, China Still Fears Its Military Isn’t Growing Fast Enough.” The Washington Post, 7 March 2014. Accessed 26 November 2014.

http://www.washingtonpost.com/world/asia_pacific/as-budgets-soar-china-still-fears-itsmilitary-isnt-growing-fast-enough/2014/03/06/e90c448a-a52e-11e3-84d4e59b1709222c_story.html.

Wang, Bernard P. "Time for a New Dance Partner: Phase Zero Engagement of NGOs in PACOM's Security Cooperation Plan.” Report, Naval War College, Newport, 2008.

Warner, Koko. "Environmental Change and Migration: Methodological Considerations from Ground-Breaking Global Survey.” Population and Environment 33, no. 1 (2011): 3-27. Accessed 2 August 2014. http://search.proquest.com/docview/ 895310004 ?accountid=28992.

Webersik, Christian. Climate Change and Security: A Gathering Storm of Global Challenges. Denver: Praeger, 2010.

Welzer, Harald. Climate Wars: Why People will be Killed in the $21^{\text {st }}$ Century. Malden: Polity Press, 2012.

West Philippine Sea Informal Expert Group. “Towards a Strategic Framework for Management of the West Philippine Sea.” White Paper, 2012. Accessed 26 November 2014. http://www.imoa.ph/towards-strategic-framework-management-west-philippine-sealwhite-paper-wps-informal-expert-group/.

Yusuf, Arief Anshory, and Herminia Francisco. "Climate Change Vulnerability Mapping for Southeast Asia.” Economy and Environment Program for Southeast Asia, January 2009. Accessed 19 March 2015. http://web.idrc.ca/uploads/user-S/12324196651 Mapping_Report.pdf. 